DOE/ID-22255

Prepared in cooperation with the U.S. Department of Energy

Completion Summary for Boreholes USGS 148, 148A, and 149 at the Materials and Fuels Complex, Idaho National Laboratory, Idaho

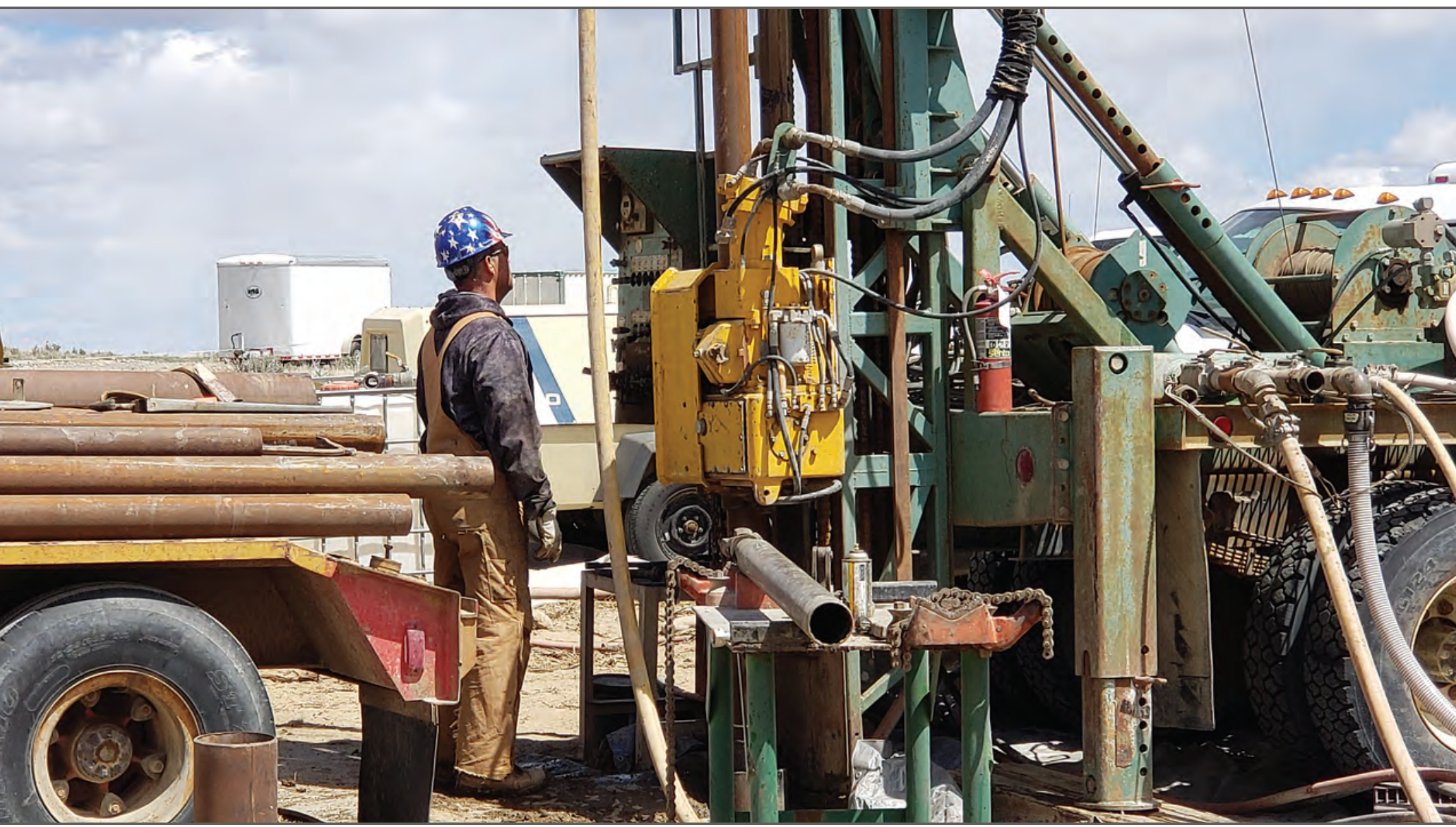

Scientific Investigations Report 2021-5131 
Cover. U.S. Geological Survey (USGS) driller core-drilling borehole USGS 149 at the Idaho National Laboratory, Idaho. Photograph by USGS, May 2019. 


\section{Completion Summary for Boreholes USGS 148, 148A, and 149 at the Materials and Fuels Complex, Idaho National Laboratory, Idaho}

By Brian V. Twining, Neil V. Maimer, Roy C. Bartholomay, and Blair W. Packer

DOE/ID-22255

Prepared in cooperation with the U.S. Department of Energy

Scientific Investigations Report 2021-5131 


\section{U.S. Geological Survey, Reston, Virginia: 2021}

For more information on the USGS - the Federal source for science about the Earth, its natural and living resources, natural hazards, and the environment—visit https://www.usgs.gov or call 1-888-ASK-USGS.

For an overview of USGS information products, including maps, imagery, and publications, visit https://store.usgs.gov/.

Any use of trade, firm, or product names is for descriptive purposes only and does not imply endorsement by the U.S. Government.

Although this information product, for the most part, is in the public domain, it also may contain copyrighted materials as noted in the text. Permission to reproduce copyrighted items must be secured from the copyright owner.

Suggested citation:

Twining, B.V., Maimer, N.V., Bartholomay, R.C., and Packer, B.W., 2021, Completion summary for boreholes USGS 148, 148A, and 149 at the Materials and Fuels Complex, Idaho National Laboratory, Idaho: U.S. Geological Survey Scientific Investigations Report 2021-5131 (D0E/ID-22255), 38 p., https://doi.org/10.3133/sir20215131.

ISSN 2328-0328 (online) 


\section{Contents}

Abstract

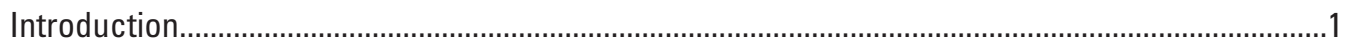

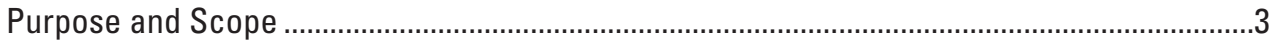

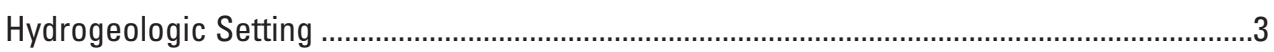

Drilling and Borehole Construction Methods …………….........................................................

Borehole USGS 148 and USGS 148A—Core Drilling and Construction ...................................

Boreholes USGS 148 and 148A Drilling Activity................................................................

Borehole USGS 149—Core Drilling and Construction ...............................................................7

Borehole USGS 149 Drilling Activity ..........................................................................................

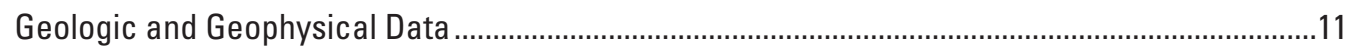

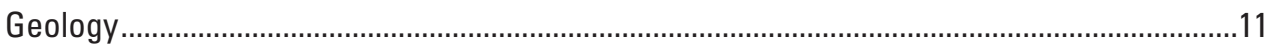

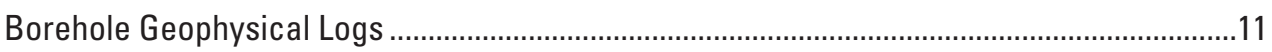

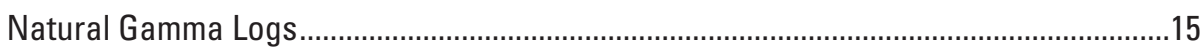

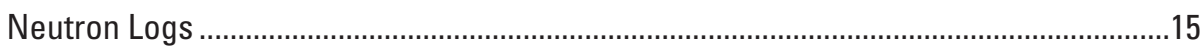

Gamma-Gamma Dual Density Logs .........................................................................15

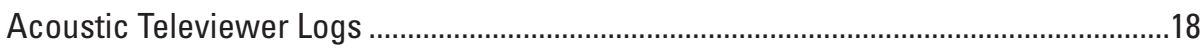

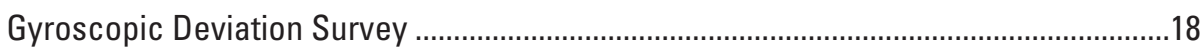

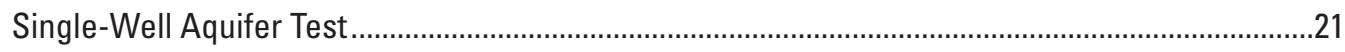

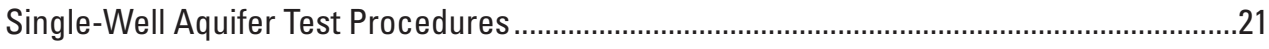

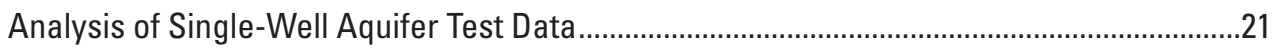

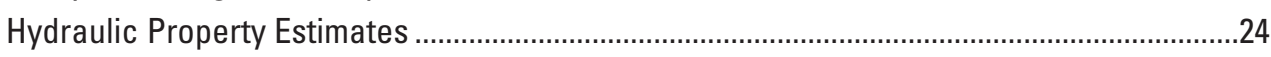

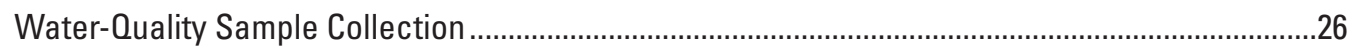

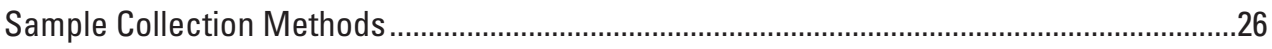

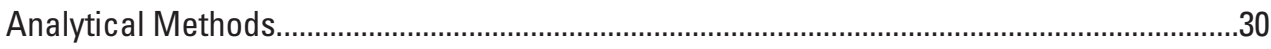

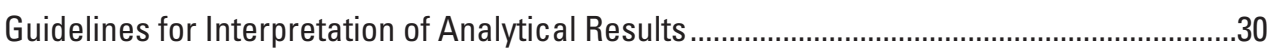

Inorganic Chemistry Data.................................................................................................

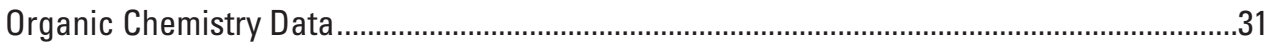

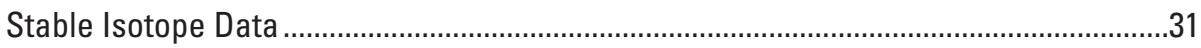

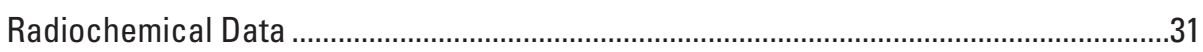

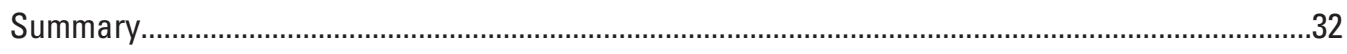

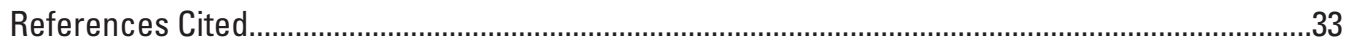

Appendix 1. Completion Report for Multilevel Well USGS 149 ....................................................38

Appendix 2. Driller Log for USGS 148A (Previously USGS 148) ..................................................38

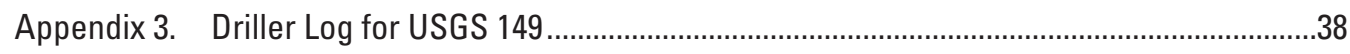

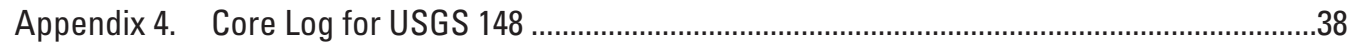

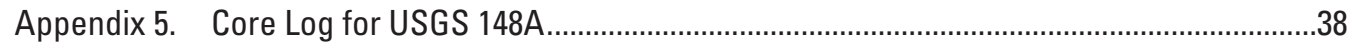

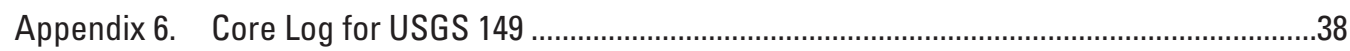




\section{Figures}

1. Map showing location of boreholes USGS 148A and USGS 149 and select monitor wells in the Materials and Fuels Complex, and location of selected facilities, Idaho National Laboratory, Idaho.....

2. Diagram, photograph, and graphs showing idealized typical olivine tholeiite pahoehoe basalt flow. . .4

3. Diagram and photographs showing $P \mathrm{P}^{\mathrm{TM}}$-size coring system used for coring..................6

4. Diagram showing final constructed well USGS 148A, Materials and Fuels Complex, Idaho National Laboratory, Idaho.

5. Diagram showing final constructed well USGS 149 with multilevel completion, Materials and Fuels Complex, Idaho National Laboratory, Idaho.

6. Borehole geophysical logs (including natural gamma, neutron, and gamma-gamma, well design) and generalized lithology described from cores, video logs, and geophysical logs for borehole USGS 148A, Materials and Fuels Complex, Idaho National Laboratory, Idaho

7. Borehole geophysical logs (including natural gamma, neutron, and gamma-gamma, well design) and generalized lithology described from cores, video logs, and geophysical logs for borehole USGS 149, Materials and Fuels Complex, Idaho National Laboratory, Idaho

8. Expanded geophysical and lithologic logs with focus on depths 655-757 feet below land surface for borehole USGS 148A, Materials and Fuels Complex, Idaho National Laboratory, Idaho

9. Expanded geophysical and lithologic logs with focus on depths $640-960$ feet below land surface for borehole USGS 149, Materials and Fuels Complex, Idaho National Laboratory, Idaho.

10. Diagram showing gyroscopic deviation survey data for boreholes USGS $148 \mathrm{~A}$ and 149 plotted as profiles in a bull's-eye view that shows horizontal offset and direction, Materials and Fuels Complex, Idaho National Laboratory, Idaho

11. Idealized schematic showing pressure sensor and pump placement during the single-well aquifer test at well USGS 148A, Materials and Fuels Complex, Idaho National Laboratory, Idaho.

12. Graphs showing changes in compensated pressure head and fluid temperature, and barometric pressure and air temperature through time, during the single-well aquifer test in well USGS 148A, Materials and Fuels Complex, Idaho National Laboratory, Idaho, November 6-7, 2019.

13. Graph showing measured pumping rates during the single-well aquifer test at well USGS 148A, Materials and Fuels Complex, Idaho National Laboratory, Idaho, November 6-7, 2019

14. Graph showing single-well aquifer test drawdown, represented as compensated fluid pressure and manual water-level measurements over time collected for well USGS 148A, Materials and Fuels Complex, Idaho National Laboratory, Idaho, November 6-7, 2019.

15. Piper diagram showing cation and anion water chemistry for well USGS $148 \mathrm{~A}$ and within four discrete zones in multilevel well USGS 149, Materials and Fuels Complex, Idaho National Laboratory, Idaho 


\section{Tables}

1. Location and completion information for wells USGS 148A and 149, Materials and Fuels Complex, Idaho National Laboratory, Idaho..

2. Summary of borehole geophysical and borehole video data collected from boreholes USGS 148A and 149, Materials and Fuels Complex, Idaho National Laboratory, Idaho.

3. Gyroscopic deviation survey data shown in 50-foot increments for boreholes USGS 148A and 149, Materials and Fuels Complex, Idaho National Laboratory, Idaho.

4. Comparison of transmissivity values estimated from aquifer tests done at wells near USGS 148A, Materials and Fuels Complex, Idaho National Laboratory, Idaho.......26

5. Concentrations of selected chemical and radiochemical constituents in water from well USGS 148A and select zones from multilevel well USGS 149, Materials and Fuels Complex, Idaho National Laboratory, Idaho, November 4-7, 2019

\section{Conversion Factors}

U.S. customary units to International System of Units

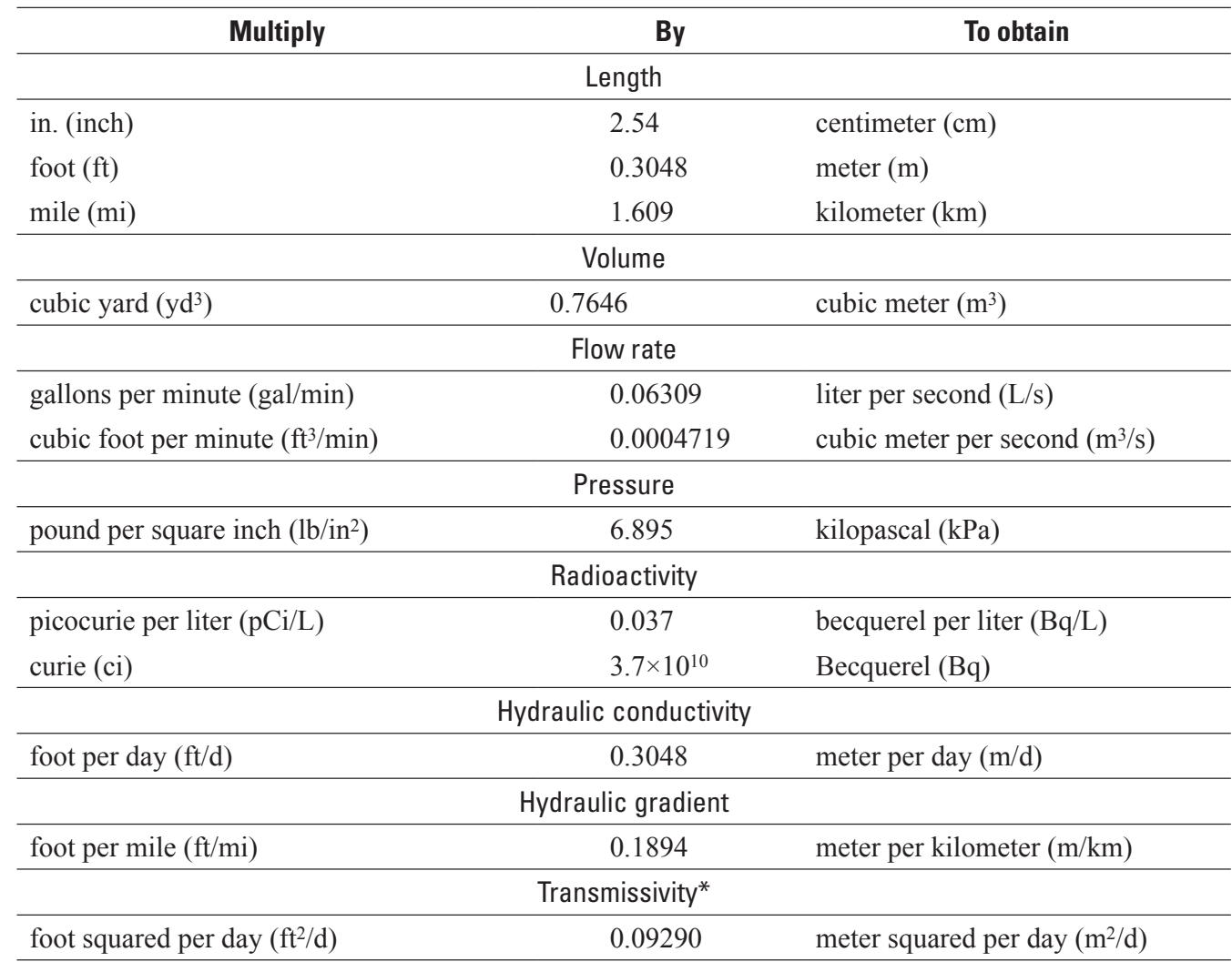


International System of Units to U.S. customary units

\begin{tabular}{lcl}
\hline \multicolumn{1}{c}{ Multiply } & By & To obtain \\
\hline & Length & \\
\hline micrometer $(\mu \mathrm{m})$ & 0.00003937 & inch (in.) \\
\hline \multicolumn{3}{l}{ Volume } \\
\hline liter $(\mathrm{L})$ & 0.2642 & gallon (gal) \\
\hline microgram $(\mu \mathrm{g})$ & 0.0000000352739 & ounce, avoirdupois $(\mathrm{oz})$ \\
milligram $(\mathrm{mg})$ & 0.0000352739 & ounce, avoirdupois $(\mathrm{oz})$ \\
\hline
\end{tabular}

Temperature in degrees Celsius $\left({ }^{\circ} \mathrm{C}\right)$ may be converted to degrees Fahrenheit $\left({ }^{\circ} \mathrm{F}\right)$ as follows:

${ }^{\circ} \mathrm{F}=\left(1.8 \times{ }^{\circ} \mathrm{C}\right)+32$.

*Transmissivity: The standard unit for transmissivity is cubic foot per day per square foot times foot of aquifer thickness [(ft3/d)/ft²] $\mathrm{ft}$. In this report, the mathematically reduced form, foot squared per day $\left(\mathrm{ft}^{2} / \mathrm{d}\right)$, is used for convenience.

\section{Datums}

Vertical coordinate information is referenced to the North American Vertical Datum of 1988 (NAVD 88).

Horizontal coordinate information is referenced to the North American Datum of 1983 (NAD 83).

Elevation, as used in this report, refers to distance above the vertical datum.

\section{Supplemental Information}

Concentrations of chemical constituents in water are given in either milligrams per liter (mg/L) or micrograms per liter ( $\mu \mathrm{g} / \mathrm{L})$.

Activities for radioactive constituents in water are given in picocuries per liter ( $\mathrm{pCi} / \mathrm{L})$. 


\section{Abbreviations}

$\begin{array}{ll}\text { ATR Complex } & \text { Advanced Test Reactor Complex } \\ \text { ATV } & \text { acoustic televiewer } \\ \text { BLS } & \text { below land surface } \\ \text { CFA } & \text { Central Facilities Area } \\ \text { CPS } & \text { counts per second } \\ \text { DLDQC } & \text { detection limits from DOCALC } \\ \text { DOE } & \text { Department of Energy } \\ \text { DQCALC } & \text { detection and quantification calculation } \\ \text { ESRP } & \text { eastern Snake River Plain } \\ \text { INL } & \text { Idaho National Laboratory } \\ \text { MFC } & \text { Materials and Fuels Complex } \\ \text { MRL } & \text { minimum reporting level } \\ \text { NTU } & \text { nephelometric turbidity units } \\ \text { NWOL } & \text { National Water Quality Laboratory } \\ \text { PVC } & \text { polyvinyl chloride } \\ \text { RESL } & \text { Radiological and Environmental Sciences Laboratory } \\ \text { RSIL } & \text { Reston Stable Isotope Laboratory } \\ \text { SS } & \text { stainless steel } \\ \text { USGS } & \text { U.S. Geological Survey } \\ \text { VOC } & \text { volatile organic compound } \\ \end{array}$





\title{
Completion Summary for Boreholes USGS 148, 148A, and 149 at the Materials and Fuels Complex, Idaho National Laboratory, Idaho
}

\author{
By Brian V. Twining, Neil V. Maimer, Roy C. Bartholomay, and Blair W. Packer
}

\section{Abstract}

In 2019, the U.S. Geological Survey (USGS), in cooperation with the U.S. Department of Energy, drilled and constructed boreholes USGS 148A and USGS 149 for stratigraphic framework analyses and long-term groundwater monitoring of the eastern Snake River Plain aquifer at the Idaho National Laboratory (INL) in southeastern Idaho. Initially, boreholes USGS 148A and USGS 149 were continuously cored to allow the USGS and INL subcontractor to collect select geophysical and seismic data and evaluate properties of recovered core material. The USGS geophysical data and descriptions of core material are described in this report; however, data collected by the INL contractor, including seismic data, are not included as part of the report.

The unsaturated zone at both borehole locations is relatively thick, depth to water was measured at approximately 663.6 feet (ft) below land surface (BLS) in USGS 148A, and at approximately $654.1 \mathrm{ft}$ BLS at USGS 149 . On completion of coring and data collection, both boreholes (USGS 148A and USGS 149) were repurposed as monitoring wells. Well USGS $148 \mathrm{~A}$ was constructed to a depth of $759 \mathrm{ft}$ BLS and instrumented with a dedicated submersible pump and measurement line; well USGS 149 was constructed to a depth of $974 \mathrm{ft}$ BLS and instrumented with a multilevel monitoring system (Westbay ${ }^{\mathrm{TM}}$ ).

Geophysical data, collected by the USGS, were used to characterize the subsurface geology and aquifer conditions. Natural gamma log measurements were used to assess sediment-layer thickness and location. Neutron and gammagamma source logs were used to confirm fractured and vesicular basalt identified for aquifer testing and multilevel monitoring well zone testing. Acoustic televiewer logs, collected for well USGS 149, were used to identify fractures and assess groundwater movement when compared with neutron measurements. Furthermore, gyroscopic deviation measurements were used to measure horizontal and vertical displacement for the constructed boreholes USGS 148A and USGS 149.

A single-well aquifer test was done in well USGS 148A during November 6-7, 2019, to provide estimates of transmissivity and hydraulic conductivity. Estimates for transmissivity and hydraulic conductivity were $6.34 \times 10^{3}$ feet squared per day and 3.17 feet per day, respectively. The aquifer test was run overnight (21.3 hours) and measured drawdown was relatively small $(0.09 \mathrm{ft})$ at sustained pumping rates ranging from 15.7 to 16.1 gallons per minute. The transmissivity estimates for well USGS 148A were slightly lower than those determined from previous aquifer tests for wells near the Materials and Fuels Complex, but well within range of other aquifer tests done at the INL.

Water-quality samples, collected from well USGS 148A and from four zones in well USGS 149, were analyzed for cations, anions, metals, nutrients, volatile organic compounds, stable isotopes, and radionuclides. Water samples for most of the inorganic constituents showed similar chemistry in USGS 148A and all four zones in USGS 149. Water samples for stable isotopes of oxygen and hydrogen indicated some possible influence of irrigation on the water quality. Nitrate plus nitrite concentrations indicated influence from anthropogenic sources. The volatile organic compound and radiochemical data indicated that wastewater disposal practices at the Materials and Fuels Complex or from drilling had no detectable influence on these wells.

\section{Introduction}

The U.S. Geological Survey (USGS), in cooperation with the U.S. Department of Energy (DOE), has collected borehole information at the Idaho National Laboratory (INL) in southeastern Idaho since 1949 to provide baseline data on the migration and disposition of radioactive and chemical wastes in the eastern Snake River Plain (ESRP) aquifer. The USGS is refining numerical models for the movement of groundwater and contaminants in the ESRP aquifer. Additional hydrogeologic and borehole information at and near the Materials and Fuels Complex (MFC) is needed to better understand groundwater flow for ongoing studies (fig. 1). Geologic data along with hydraulic properties (transmissivity and hydraulic conductivity) are needed to define groundwater movement as it relates to contaminant transport of waste plumes at the MFC. 


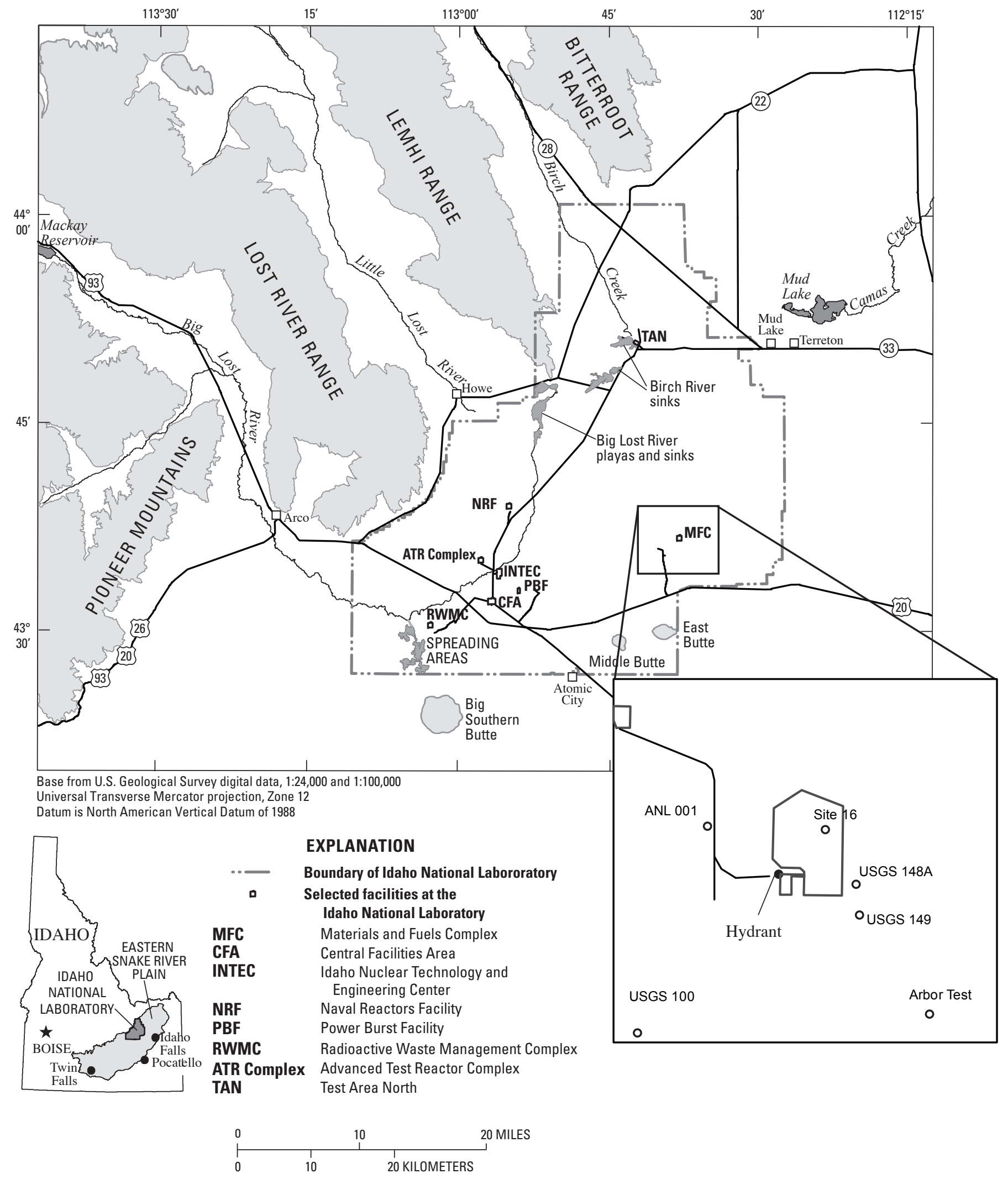

Figure 1. Location of boreholes USGS 148A and USGS 149 and select monitor wells in the Materials and Fuels Complex, and location of selected facilities, Idaho National Laboratory, Idaho. USGS, U.S. Geological Survey. 
Drilling and data collection for boreholes USGS 148A and USGS 149 included the collection and analysis of drill core and geologic data. After completion of data collection, the USGS successfully repurposed the wells to meet monitoring objectives. Well USGS 148A was repurposed as a monitor well using a submersible pump and measurement line; well USGS 149 was repurposed with a modular multilevel monitoring system, similar to those presented in Fisher and Twining (2011) and Twining and Fisher (2012, 2015).

The USGS mobilized and began drilling at borehole USGS 149 on April 29, 2019 (fig. 1). Borehole USGS 149 was cored and constructed in two phases. During the first phase, starting on April 29, 2019, and ending on May 29, 2019, the borehole was continuously cored from 6.5 to 758.0 feet (ft) below land surface (BLS). The DOE required this depth to meet geophysical and seismic data collection requirements for the MFC, work performed by the INL contractor and outside the scope of this report. During the second phase, starting on August 26, 2019, and ending on September 20, 2019, borehole USGS 149 was cored from 758.0 to $973.7 \mathrm{ft}$ BLS. After completion of drilling at borehole USGS 149, a modular monitoring system was installed over 4 days, starting on September 23, 2019. The system selected, Westbay ${ }^{\mathrm{TM}}$ MP55, uses technology deployed in other USGS wells at the INL to monitor pressure, temperature, and water chemistry from discrete zones using a series of packers and measurement ports. A description of the system, components, port depths, and zones is provided in appendix 1 .

Core drilling for borehole USGS 148A (previously USGS 148) started on July 2, 2019, and was completed on July 30 , 2019. Borehole USGS 148 was abandoned during June 12-19, 2019, after core drilling from the first basalt contact down to a depth of $264.1 \mathrm{ft}$ BLS. Boreholes USGS 148 and USGS 148A originate from the same surface location; however, borehole USGS 148 was abandoned at depths of 136.5-264.1 ft BLS after polyvinyl chloride (PVC) tremie pipe broke off while we attempted to stabilize rubble sections with grout. The PVC tremie pipe broke off on June 27, 2019, after we placed a total of 43.5 cubic yards $\left(\mathrm{yd}^{3}\right)$ of grout over several days through the abandoned section. Attempts were made to drill over the PVC pipe and use the same cored borehole (USGS 148), but at a depth near $130.0 \mathrm{ft}$ BLS, we determined that the bit was no longer in the section previously cored. A decision was made to rename the borehole USGS 148A, allowing for some overlap in core material between boreholes USGS 148 and USGS 148A. Core drilling resumed in borehole USGS 148A at a depth of $136.5 \mathrm{ft}$ BLS on July 2, 2019; borehole USGS 148A was continuously cored from $136.5 \mathrm{ft}$ to $759.2 \mathrm{ft}$ BLS over 17 days. After drilling, borehole USGS 148A was repurposed as a monitoring well and used for aquifer testing and groundwater sampling. Driller notes for boreholes 148A (previously USGS 148) and USGS 149 are provided in appendixes 2 and 3 , respectively.

Various data were collected throughout the drilling process and after the boreholes were constructed as monitor wells; much of these data are presented in this report.
Recovered borehole cores for boreholes USGS 148, 148A, and 149 were photographed and described and are included in appendixes 4-6, respectively. Geophysical and borehole video data, collected by the USGS, were analyzed to show and describe the borehole conditions and confirm areas of sediment along with areas of fractured and dense basalt.

\section{Purpose and Scope}

The purpose of this study is to better understand the hydrogeology in the eastern part of the INL, specifically at the MFC. The scope of this report presents results of the drilling, coring, construction, geophysical logging, and groundwater sample results for boreholes USGS 148A and USGS 149 along with the aquifer test results for well USGS 148A. Select drilling and core data are presented for abandoned borehole USGS 148. General lithologic descriptions of the drill core for all boreholes are provided along with detailed descriptions that are presented in the accompanying appendixes. This report also presents (1) a comprehensive suite of water samples analyzed for inorganic, organic, stable isotopes, and radionuclide constituents; and (2) results for wells USGS 148A and USGS 149.

\section{Hydrogeologic Setting}

The INL is in the west-central part of the ESRP (fig. 1). The ESRP is a northeast-trending structural basin about 200 miles (mi) long and 50-70 mi wide. Formation of the ESRP was caused by the passage of the North American tectonic plate over the Yellowstone Hot Spot (Pierce and Morgan, 1992). The ESRP is subject to continuing basaltic volcanism and subsidence because disruption to the crust resulted in increased heat flow (Blackwell and others, 1992) and emplacement of a dense, mid-crustal sill (Shervais and others, 2006). The subsiding ESRP basin was filled with interbedded terrestrial sediments and Pleistocene to late Pliocene basalt, 0.6-1.2 mi thick (Whitehead, 1992). The basaltic rocks and sedimentary deposits constitute the ESRP aquifer.

The ESRP is composed mostly of olivine tholeiite basalt flows, which erupted as tube-fed, inflated, pahoehoe flows that constitute more than 85 percent of the subsurface volume of the ESRP at the INL (Anderson and Liszewski, 1997). Figure 2 shows a diagram of a lobe of a tube-fed pahoehoe ESRP basalt flow with cooling fractures that develop perpendicular to the exterior surfaces, vesicle zones and sheets, pipe vesicles, interior mega vesicles, and a diktytaxitic to massive core. The distribution of basalt flows is controlled by topography, rate of effusion, and duration of eruption. Near-vent flows are thinner than distal flows, and accumulations of thin flows have a larger volume of high conductivity zones than the same volume of thick flows (Anderson and others, 1999).

The part of the Snake River Plain aquifer that underlies the ESRP is one of the most productive aquifers in the United States (U.S. Geological Survey, 1985, p. 193). Groundwater in 


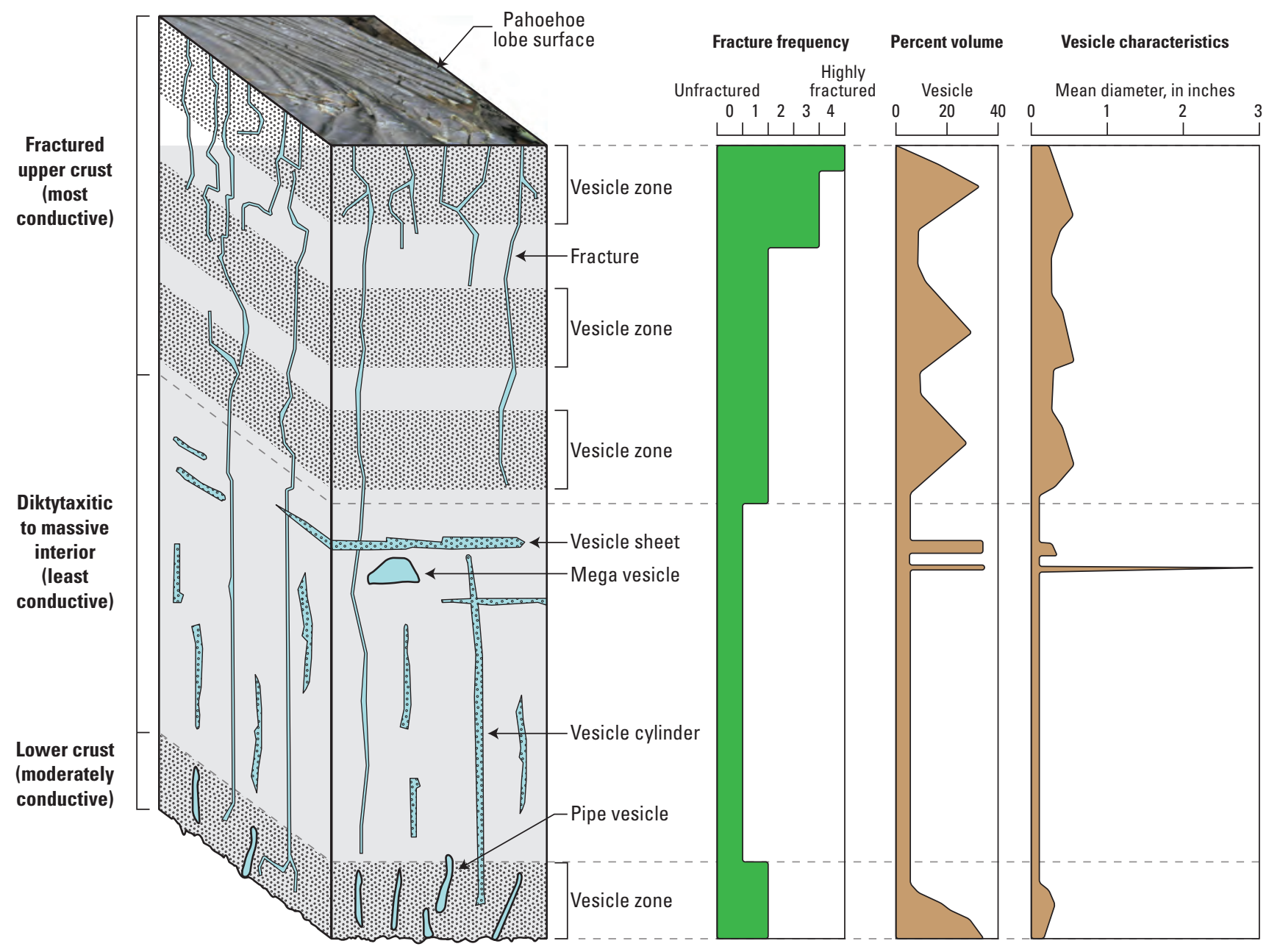

Figure 2. Idealized typical olivine tholeiite pahoehoe basalt flow (modified from Self and others, 1998, fig. 3, p. 90). Basalt flow is divided into three sections based on vesicle characteristics and fracture frequency. Hydraulic conductivity is highest for the fractured upper crust, moderate for the lower crust, and lowest for the diktytaxitic to massive interior. Photograph of pahoehoe lobe surface used with permission of Scott Hughes, Emeritus Professor, Idaho State University, Pocatello, Idaho.

the ESRP aquifer generally moves from northeast to southwest, eventually discharging to springs along the Snake River near the terminus of the ESRP_-about 100 mi southwest of the INL (Whitehead, 1992). Water moves through basalt fracture zones at the tops, bases, and sides of basalt flows. Infiltration of surface water, groundwater pumping, geologic conditions, and seasonal fluxes of recharge and discharge locally affect the movement of groundwater (Garabedian, 1986). Recharge to the ESRP aquifer primarily is from infiltration of applied irrigation water, streamflow, precipitation, and groundwater inflow from adjoining mountain drainage basins (Ackerman and others, 2006).

The depth to water in wells completed in the ESRP aquifer at the INL ranges from about $200 \mathrm{ft}$ in the northern part of the site to more than $900 \mathrm{ft}$ in its southeastern part. A substantial proportion of the groundwater moves through the upper 200-800 ft of basaltic rocks (Mann, 1986, p. 21). Ackerman (1991, p. 30), Bartholomay and others (1997, table 3), and Twining and Maimer (2019, table 2) reported a range for transmissivity in the ESRP aquifer of 1.1-760,000 feet squared per day $\left(\mathrm{ft}^{2} / \mathrm{d}\right)$. The hydraulic gradient at the INL ranges from 2 to 10 feet per mile (ft/mi), with an average of $4 \mathrm{ft} / \mathrm{mi}$ (Bartholomay and others, 2020, fig. 9). Horizontal flow velocities of about 2-26 ft/d have been calculated based on the movement of various constituents in different areas of the aquifer at and near the INL (Robertson and others, 1974; Mann and Beasley, 1994; Cecil and others, 2000; Plummer and others, 2000; Busenberg and others, 2001). These flow rates equate to a travel time of 55-700 years for water beneath the INL to travel to springs that discharge at the terminus of the ESRP aquifer. Localized tracer tests at the INL have indicated vertical- and horizontal-transport rates as high as 60-150 $\mathrm{ft} / \mathrm{d}$ (Nimmo and others, 2002; Duke and others, 2007). 


\section{Drilling and Borehole Construction Methods}

Drilling and well construction by the USGS took place during April 30-November 7, 2019. All activities were in accordance with the USGS INL Site Safety Plan and the INL environmental checklist requirements. Prior to drilling, a pre-job safety briefing was held on April 29, 2019, at borehole USGS 149, and a second briefing was held on June 12, 2019, for borehole USGS 148A (previously USGS 148). In addition to the pre-job briefings, daily job-site briefs were held between the USGS and the sub-contractor collecting seismic data to keep off-site management updated on the schedule, drilling, and safety. Regular equipment inspections and safety discussions were documented, and weekly drilling updates were distributed by email during the project.

Prior to the start of drilling, protective tarps were placed under the drill rig and various other support equipment to prevent spills of oil and (or) hydraulic fluids. No reportable spills occurred during drilling operations. Drilling water, mixed with drilling mud, was used throughout the drilling and coring process. Drilling water was supplied from a fire hydrant located in the parking lot of the MFC (fig. 1). Drilling mud, consisting of bentonite and polymer materials, was mixed on-site with drill water and introduced as drilling fluid while drilling occurred. Drilling fluid primarily was used to maintain borehole stability and cool the drill bit while core drilling occurred. Cement grout (grout) was used to fill fractures and stabilize loose sections of material. Grout generally consisted of Portland Type II cement, bentonite, and water. Grout was mixed at the drill site to achieve a thick slurry and pumped through 2-inch (in.) tremie line to desired depths until the borehole was filled.

\section{Borehole USGS 148 and USGS 148A-Core Drilling and Construction}

Borehole USGS 148 was continuously cored from 3.6 to 264.1 ft BLS (app. 4); Borehole USGS 148A was continuously cored from about 136.5 to $759.2 \mathrm{ft} \mathrm{BLS} \mathrm{(app.} \mathrm{5).} \mathrm{Borehole}$ USGS 148 was abandoned with grout below $136.5 \mathrm{ft}$ BLS; however, boreholes USGS 148 and USGS 148A are the same borehole down to this depth (136.5 ft BLS).

Core drilling was done using a Christensen ${ }^{\mathrm{TM}}$ CS 1500 rotary drilling rig and $\mathrm{PQ}^{\mathrm{TM}}$-size coring system (fig. 3; Christensen Products, 1997), where $\mathrm{PQ}^{\mathrm{TM}}$ refers to core rod sizing (drill-bit size about 4.8-in. diameter). The core system was set up with carbide and diamond core bits, core catchers, and latch assembly for core retrieval (fig. 3). Core was retrieved in 5-ft sections using a four-part wireline latching mechanism (quad latch) at the top of the core-barrel assembly (fig. 3). The core was marked for orientation and depth in the field before boxing. Additionally, the cores from USGS 148 and USGS 148A were reviewed and taken to the USGS Lithologic Core Storage Library (CFA-663) - the library is operated by the USGS and located at Central Facilities Area (CFA; fig. 1) to be photographed and archived. The completed core logs for USGS 148 and USGS 148A, with photographs and core descriptions, are included in appendixes 4 and 5, respectively.

\section{Boreholes USGS 148 and 148A Drilling Activity}

Core drilling at the initial borehole USGS 148 started on June 12, 2019, after placement of steel well casing with 5.0-in. inside diameter near $3.6 \mathrm{ft}$ BLS at the first basalt contact. Core drilling for borehole USGS 148 advanced quickly from 3.6 to $264.1 \mathrm{ft}$ BLS during June 12-19, 2019; however, because of unstable conditions, attempts were made to grout fractures and stabilize the borehole. A total of $43.5 \mathrm{yd}^{3}$ of grout was pumped through tremie and used to fill the borehole during June 20-27, 2019. Most of the grout moved out horizontally through fractures in the basalt matrix. On June 27, 2019, 3.5 $\mathrm{yd}^{3}$ of grout was pumped, the grout suddenly filled up past the bottom of the PVC tremie pipe.

After attempts to remove the tremie pipe failed, the USGS attempted to use a modified drill bit to drill out the PVC tremie, but also to stay within the original cored borehole (USGS 148). Near a depth of $130.0 \mathrm{ft}$ BLS, basalt cutting returns suggested that the drill bit had moved out of borehole USGS 148, starting a new borehole renamed USGS 148A. The USGS restarted core drilling at borehole USGS 148A near a depth of 136.5 on July 1, 2019. Given the amount of grout placed in original cored borehole USGS 148 (43.5 $\left.\mathrm{yd}^{3}\right)$, the drilling group believed that the cement grout had filled most, if not all, of the section of cored borehole extending from 136.5 to $264.1 \mathrm{ft}$ BLS.

Core drilling resumed in borehole USGS 148A; however, near a depth of $314.0 \mathrm{ft}$ BLS, $24.5 \mathrm{yd}^{3}$ of grout were placed over 2 days in borehole USGS 148A to stabilize fractured areas. The grout was pumped through tremie until it reached land surface, grouting through sections previously grouted. Before the grout had fully cured, it was drilled out using a tri-cone assembly following borehole USGS 148A. After the grouted section was drilled out to $314 \mathrm{ft} \mathrm{BLS}$, core drilling resumed for 11 days to a final completion depth of $759.2 \mathrm{ft}$ BLS on July 30, 2020. In total, approximately $68.0 \mathrm{yd}^{3}$ of grout was used to fill fractures throughout the upper 314.0 $\mathrm{ft}$ of borehole USGS 148A. After borehole USGS 148A was drilled to completion depth, geophysical data were collected and analyzed by the USGS. 

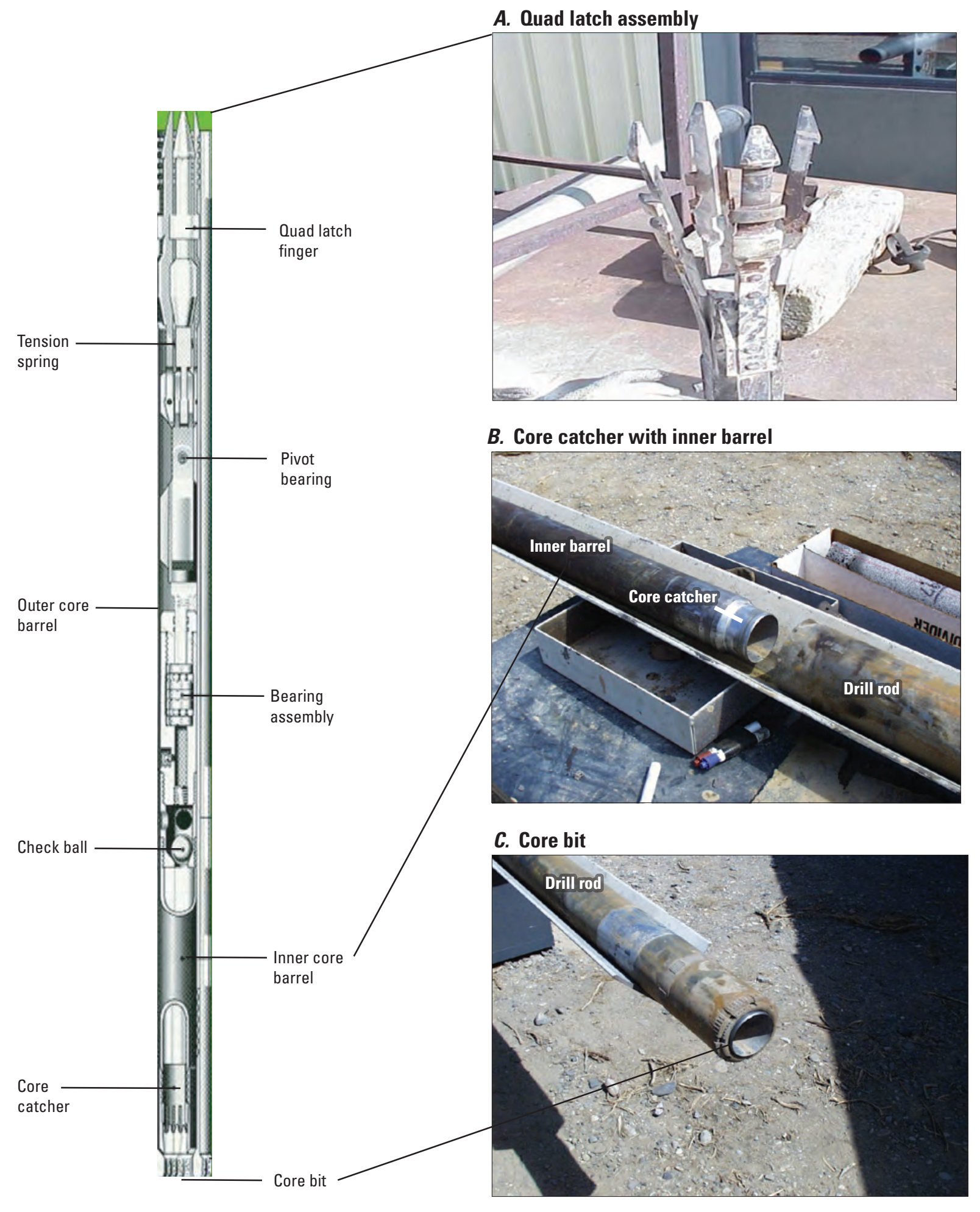

Modified from Twining and others (2014).

Figure 3. $P Q^{T M}$-size coring system used for coring. $P Q^{T M}$ refers to core rod sizing (drill-bit size is about 4.8 inches in outer diameter). Modified from Christensen Products, 1997. 
Final construction of well USGS 148A included placement of 4.0-in. inside-diameter steel casing, extending continuously from $2.5 \mathrm{ft}$ above land surface to a depth of $654.0 \mathrm{ft}$ BLS. The 4.8-in. borehole is open below the steel casing from 654.0 to $759.2 \mathrm{ft}$ BLS (fig. 4). This was done prior to installation of a submersible pump and measurement line and to avoid potential caving of loose material. Well USGS 148A was configured with a Grundfos ${ }^{\mathrm{TM}} 5$-horsepower submersible pump, pump wire, 1.0-in. diameter stainless steel (SS) discharge line, and 1.0-in. diameter SS water-level line (fig. 4). The submersible pump intake was set near $720.0 \mathrm{ft}$ BLS for aquifer testing and well development, and the 1.0-in. diameter measuring line was installed down to about $700.0 \mathrm{ft} \mathrm{BLS}$. Surface completion included a $4.0-\mathrm{ft}$ diameter concrete pad complete with a brass survey marker and a locking wellhead (table 1; fig. 4).

\section{Borehole USGS 149—Core Drilling and Construction}

Borehole USGS 149 was continuously cored from 6.5 to $973.7 \mathrm{ft}$ BLS using a Christensen ${ }^{\mathrm{TM}} \mathrm{CS} 1500$ rotary drilling rig and $\mathrm{PQ}^{\mathrm{TM}}$-size coring system (Christensen Products, 1997). The coring methods and assembly used for drilling borehole USGS 149 were like those previously described for borehole USGS 148A (fig. 3). Core material was boxed and reviewed before it was taken to CFA-663 to be photographed and described at the INL Lithologic Core Storage Library (app. 6).

\section{Borehole USGS 149 Drilling Activity}

On April 30, 2019, drilling began on borehole 149 through approximately $3.0 \mathrm{ft}$ of surface sediment with the placement of 8.0-in. inside-diameter steel well casing to this depth. A tri-cone bit assembly (6.0-in. diameter) was used to advance the borehole through a mixture of sediment and rubble but stopped at solid basalt near $6.0 \mathrm{ft}$ BLS. Steel casing (5.0-in. inside-diameter) was placed in mostly solid rock before the previously advanced 8.0 -in. steel casing was removed. After casing through surface material, the drilling system was changed over to begin core drilling.

Core drilling for borehole USGS 149 was completed in two stages. The first stage borehole USGS 149 was cored from 6.5 to $758.0 \mathrm{ft}$ BLS during April 30-May 30, 2019; the second stage was cored from 758.0 to $973.7 \mathrm{ft}$ BLS during August 26-September 4, 2019 (app. 3). After the first stage of core drilling was completed, the USGS mobilized equipment to borehole USGS 148A, leaving borehole USGS 149 open for testing for almost 3 months. Starting on August 26, 2019, the USGS mobilized equipment back to restart the second stage of core drilling at borehole USGS 149. The USGS cored borehole USGS 149 an additional $215.7 \mathrm{ft}$, terminating the borehole at a depth of $973.7 \mathrm{ft} \mathrm{BLS}$.

During the first stage, borehole USGS 149 was cored to a depth of $233.0 \mathrm{ft}$ BLS before $32.0 \mathrm{yd}^{3}$ of grout was placed to stabilize loose sections and prevent material caving. The grout was placed over 6 days, in 2-6-yd ${ }^{3}$ batches (app. 3), filling up the cored borehole to surface. The partially cured grout was drilled out using a tri-cone bit assembly and stopping near $233.0 \mathrm{ft}$ BLS but following the previously cored section. The grout seemed to have successfully stabilized the borehole, resulting in a mostly continuous grout collar down to $233.0 \mathrm{ft}$ BLS. Core drilling resumed to a depth of $403.0 \mathrm{ft}$ BLS, but the USGS encountered additional fractured and unstable media that required grouting (app. 3). An additional $15 \mathrm{yd}^{3}$ of grout was placed over 1 day in borehole USGS 149, filling it from 234.0 to $403.0 \mathrm{ft}$ BLS. The partially cured grouted section was drilled out using the tri-cone assembly to follow the cored borehole section. The tri-cone drilling was halted near 397.0 $\mathrm{ft}$ BLS to resume core drilling. The grouting effort resulted in borehole USGS 149 having a mostly continuous grout collar, extending from the bottom of the surface casing down to 403.0 $\mathrm{ft}$ BLS (fig. 5). The continuous grout collar and stable borehole were essential for seismic testing, scheduled by the INL contractor.

The USGS completed stage 1 after core drilling from 397.0 to $758.0 \mathrm{ft}$ BLS (app. 3) and collected geophysical data with drill rod on bottom. Additionally, the USGS recorded a borehole video after removing the drill rod to review the grout collar integrity, but also to review the open section where no grouting occurred. After verifying the borehole integrity, the USGS assisted the INL contractor with data collection at both borehole locations (USGS 148A and 149) before mobilizing back to borehole USGS 149 to finish final construction and monitor well installation.

The second stage of borehole USGS 149 core drilling was completed over 4 days, reaching a depth of $973.7 \mathrm{ft}$ BLS. The USGS decided to terminate the borehole at the depth of 973.7 ft BLS because of difficulties removing the entire drilling assembly after the bit became stuck. Attempts to pull the drill assembly were not successful; however, most of the drill rod was successfully removed after deployment of a cutting tool used to separate the drill rod near $961.0 \mathrm{ft}$ BLS. Borehole video was used to confirm that borehole USGS 149 was open to approximately $961.0 \mathrm{ft}$ BLS; however, approximately 12.7 $\mathrm{ft}$ of the drill assembly remained on bottom. Because of the time involved with removing the drill rod and the preparation time needed to meet the scheduled installation of a multilevel monitoring system, only select geophysical data were collected. On September 20, 2019, the USGS collected geophysical data along with a borehole video just prior to the installation of the multilevel monitoring system, which started September 23, 2019.

The final construction of borehole USGS 149 (fig. 5) included (1) an 8.0-in. diameter steel casing extending $2.77 \mathrm{ft}$ above brass land surface datum but welded to 5.0-in. diameter steel casing set to $6.0 \mathrm{ft}$ BLS, (2) a Westbay ${ }^{\mathrm{TM}}$ MP55 multilevel monitoring system installed to a depth of $958.34 \mathrm{ft}$ BLS (app. 1), and (3) a concrete pad complete with a brass survey datum and a locking wellhead. 
USGS 148A

Site Identifier: 433535112390801

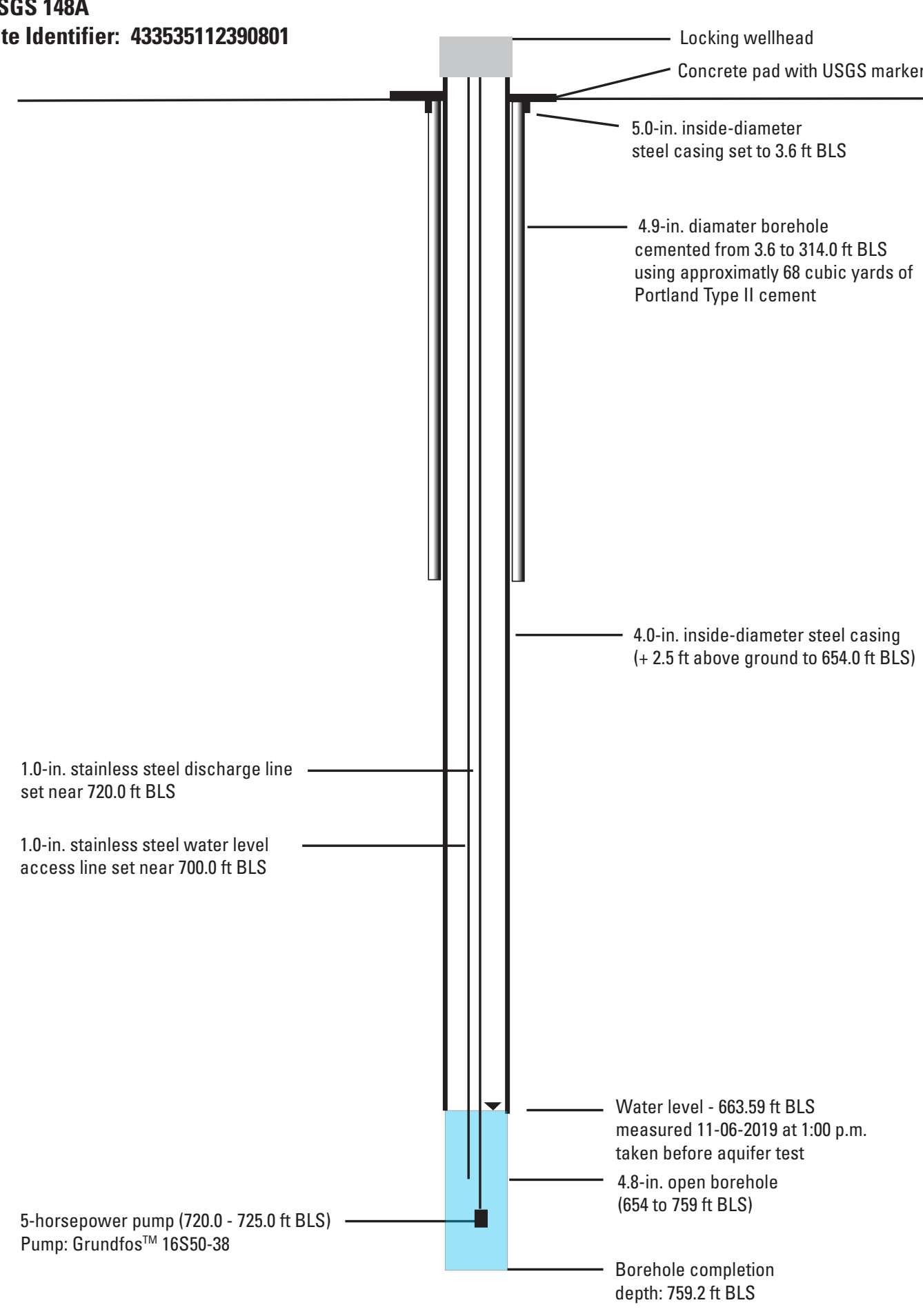

1.0-in. stainless steel discharge line set near $720.0 \mathrm{ft} \mathrm{BLS}$

1.0-in. stainless steel water level access line set near $700.0 \mathrm{ft}$ BLS

5-horsepower pump (720.0 - $725.0 \mathrm{ft} \mathrm{BLS})$ Pump: Grundfos ${ }^{\mathrm{TM}} 16 \mathrm{~S} 50-38$

Depth

(feet BLS)

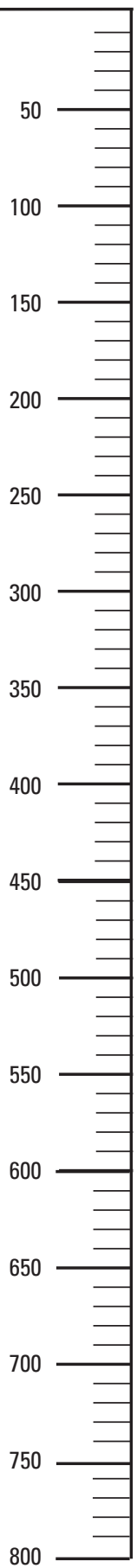

Figure 4. Final constructed well USGS 148A, Materials and Fuels Complex, Idaho National Laboratory, Idaho. in., inch; BLS, below land surface; $\mathrm{ft}$, feet; USGS, U.S. Geological Survey ;+, plus. 
Table 1. Location and completion information for wells USGS 148A and 149, Materials and Fuels Complex, Idaho National Laboratory, Idaho.

[Local name: Local well identifier used in this study. Location of well is shown in figure 2; Site identifier is unique numerical identifier used to access well data (U.S. Geological Survey, 2021). Longitude, Latitude, and Measurement point elevation are from survey taken at brass survey marker (brass cap) located adjacent to well head on cement pad. Aquifer thickness is the altitude of the base of the aquifer as interpreted from geophysical surveys (Whitehead, 1992) subtracted from the measured depth to water (altitude of water table). Depth cored (range) refers to starting and ending point of continuous core. Total core recovered refers to total amount of core recovered during drilling. Top and bottom of open borehole refers to where the casing stops and open borehole (uncased) section starts. Abbreviations and symbol: BLS, below land surface; NAD 83, North American Datum of 1983; NAVD 88, National Geodetic Vertical Datum of 1988; USGS, U.S. Geological Survey; >, greater than]

\begin{tabular}{lll}
\hline \multicolumn{1}{c}{ Local name } & \multicolumn{1}{c}{ USGS 148A } & \multicolumn{1}{c}{ USGS 149 } \\
\hline Site identifier & 433535112390801 & 433524112390801 \\
Longitude & $112^{\circ} 39^{\prime} 07.52^{\prime \prime}$ (NAD 83) & $112^{\circ} 39^{\prime} 08.29^{\prime \prime}(\mathrm{NAD} 83)$ \\
Latitude & $43^{\circ} 35^{\prime} 35.42^{\prime \prime}(\mathrm{NAD} 83)$ & $43^{\circ} 35^{\prime} 23.73^{\prime \prime}(\mathrm{NAD} 83)$ \\
Measurement point elevation & $5,140.55$ feet (NAVD 88) & $5,132.42$ feet (NAVD 88) \\
Aquifer thickness & $>2,000$ feet & $>2,000$ feet \\
Depth cored (range) & 136.3 to 759.2 feet BLS & 6.5 to 973.7 feet BLS \\
Total core recovered & 600.5 feet & 951.3 feet \\
Borehole diameter & 4.8 inches & 4.8 inches \\
Top of open borehole & 654.0 feet & 6.0 feet BLS \\
Bottom of open borehole & 759.2 feet & 973.7 feet BLS \\
Depth to water & 663.59 feet BLS, measured & 654.12 feet BLS, measured \\
& November 6, 2019, at 1:00 p.m. & September 24, 2019, at 12:30 p.m. \\
\hline
\end{tabular}


USGS 149

Site Identifier: 433524112390801

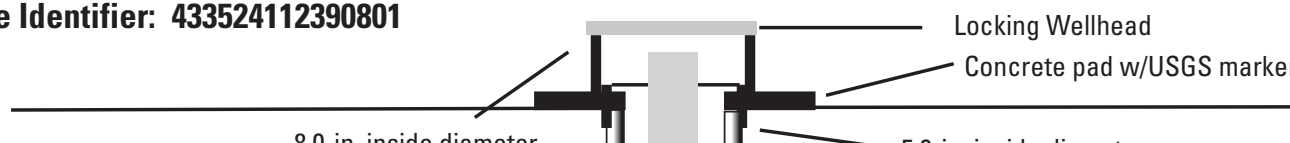

8.0-in. inside diameter steel casing

(+1 to $+2.77 \mathrm{ft}$ above

5.0-in. inside diameter

steel casing set to $6 \mathrm{ft} \mathrm{BLS}$

land surface datum)

4.8-in. diamater borehole Cemented from 6 to $403 \mathrm{ft}$ BLS

Portland Type II Cement (0 to $403 \mathrm{ft} \mathrm{BLS}$ )

51.3 yards cement pumped

through tremie pipe

MP55 packer (5 ft) - blue lines

11 packers total

MP55 casing (PVC)

MP casing length: $958.3 \mathrm{ft}$

(feet BLS)
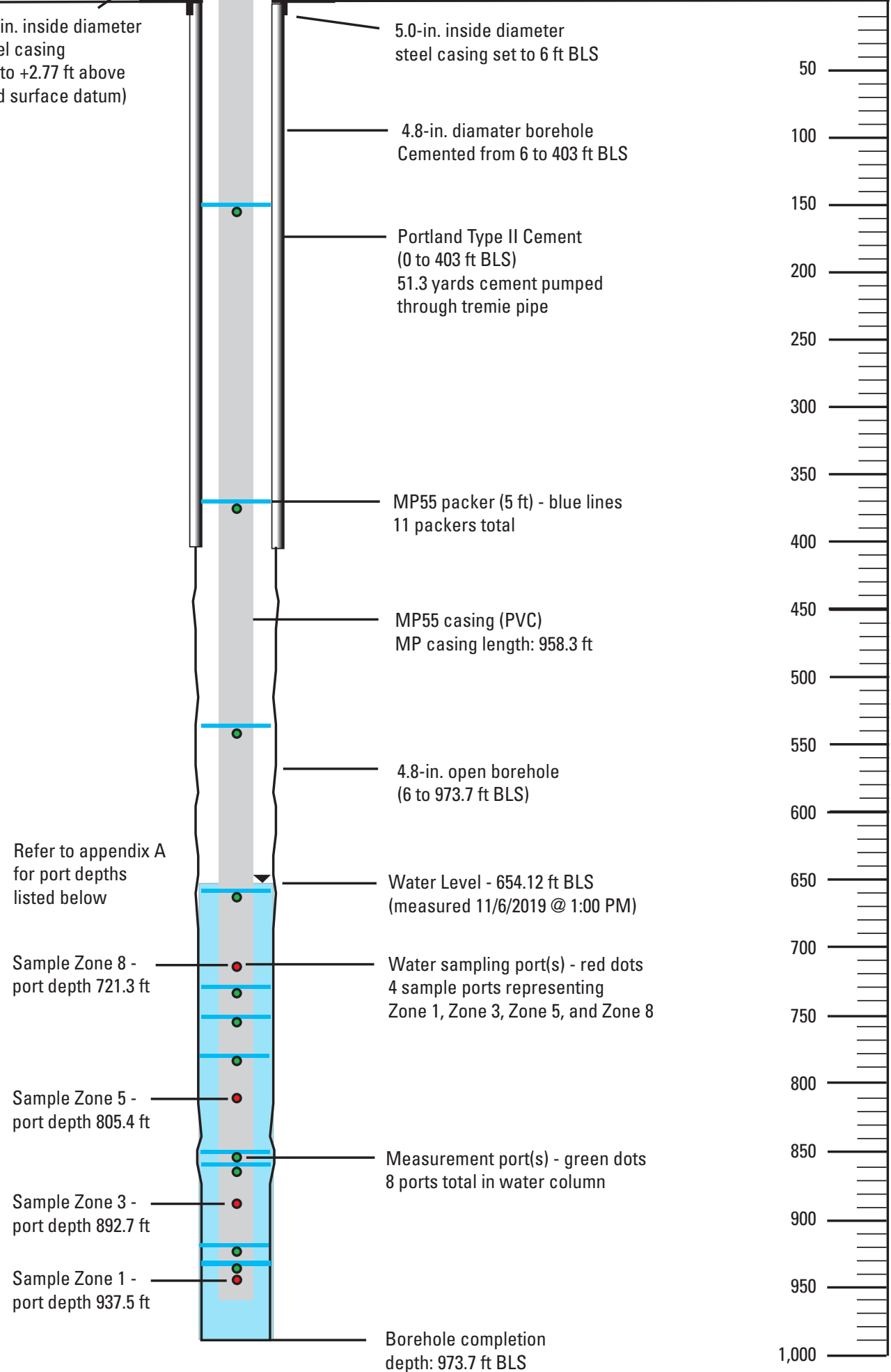

Figure 5. Final constructed well USGS 149 with multilevel completion, Materials and Fuels Complex, Idaho National Laboratory, Idaho. in., inch; BLS, below land surface; ft, feet; PVC, polyvinyl chloride; USGS, U.S. Geological Survey ;+, plus. 


\section{Geologic and Geophysical Data}

Geologic data were collected and analyzed from the core to provide rock and sediment properties. Additionally, geologic and hydrologic data were interpreted from borehole geophysical logs collected and analyzed for boreholes USGS 148A and USGS 149. Borehole geophysical data provided a complete and continuous representation of formation material in the immediate vicinity of the well bore and were used for selecting depths for geologic contacts. Recovered core material was labeled, photographed, and described to provide detailed lithologic descriptions from land surface to completion depth. Core photographs and lithologic descriptions are provided for boreholes USGS 148, 148A, and 149 in appendixes 4-6. Some core material overlap exists for boreholes USGS 148 and USGS 148A where they originate from the same surface location and follow similar geologic media; however, all core material recovered was provided as part of this investigation.

Borehole geophysical log data collected include natural gamma, neutron, gamma-gamma dual density, and gyroscopic deviation (table 2). Acoustic data were collected for borehole USGS 149 after the final completion depth was reached during stage 2. Borehole geophysical data were saved as electronic files and processed using WellCAD ${ }^{\mathrm{TM}}$ software. Processed data were used to infer changes in geologic media along with lithologic descriptions. Borehole geophysical data can be accessed through U.S. Geological Survey (2019) USGS GeoLog Locator (U.S. Geological Survey, 2019).

\section{Geology}

The surficial geology at boreholes USGS 148A and 149 is sparsely vegetated loess. Surface sediment was not cored at either location; however, drill cuttings from above the first basalt contact at boreholes USGS 148A and 149 were unconsolidated and poorly developed soil, consisting of fine to coarse sand.

Five sediment layers, excluding surficial sediments, were noted in core material descriptions and borehole geophysical logs for borehole USGS 148A (app. 5; fig. 6). Sediment descriptions for borehole USGS 148A start near a depth of $136.3 \mathrm{ft}$ BLS; however, sediment descriptions from land surface to $136.3 \mathrm{ft}$ BLS from USGS 148 were used for borehole USGS 148A because they were assumed to be the same borehole. Sediment-layer thickness for borehole USGS 148A ranged from 1.0 to $6.8 \mathrm{ft}$ and sediment layers generally were separated by $100 \mathrm{ft}$ or more of basalt. The sediment layers, described in appendixes 4-5, are composed mostly of fine-grained sand, silt, and clay deposits that were extremely firm and structureless. Sediment layers, including surficial sediment, constitute about 2.6 percent (19.9 of $759.2 \mathrm{ft}$ ) by volume of borehole USGS 148A. All the sediment described in borehole USGS 148A was described for the unsaturated zone, above $663.6 \mathrm{ft}$ BLS (fig. 6). Sediment layers recovered from boreholes USGS 148 and 148A seemed to be aeolian deposits that were deposited between recurring basalt eruptions. Sediment-layer descriptions, in appendixes 4-5, show evidence of root casts within the fine sand, silt, and clay matrix that indicate a hiatus in time sufficient to establish vegetation growth.

Six sediment layers, excluding surficial sediments, were noted in core material descriptions and borehole geophysical logs for borehole USGS 149 (app. 6; fig. 7). Lithologic descriptions for borehole USGS 149 suggest that the thickness of sediment layers for borehole USGS 149 ranged from 0.2 to $7.3 \mathrm{ft}$ and that the layers generally were separated by $100 \mathrm{ft}$ or more of basalt. The sediment, described in appendix 6 , are composed mostly of fine-grained sand, silt, and clay deposits that were extremely firm and structureless. Two sediment layers described for borehole USGS 149, but not described for borehole USGS 148A, include a volcanic ash deposit present in a sediment layer described near $35.1 \mathrm{ft} \mathrm{BLS}$ and a sandstone layer near $579.6 \mathrm{ft}$ BLS (app. 6). Sediment layers, including surficial sediment, constitute about 2.0 percent (19.8 of 973.7 $\mathrm{ft}$ ) by volume of borehole USGS 149. Like the sediment layers in borehole USGS 148A, the sediment layers described for borehole USGS 149 only account for a small percentage of the overall thickness and were not identified in the saturated section cored below about $650.0 \mathrm{ft}$ BLS (fig. 7). Sediment layers recovered for borehole USGS 149 that were deposited between recurring basalt eruption (but allowing enough time for vegetation growth) also seemed to be aeolian. Examples are described in appendix 6; they include root casts within the fine sand, silt, and clay matrix.

Basalt layers encountered in boreholes USGS 148, 148A, and 149 also are described in appendixes 4-6. The texture of basalt between boreholes was similar, but varied between aphanitic, phaneritic, diktytaxitic, and porphyritic. The cored basalt layers generally ranged from medium to dark gray in color. Lithologic descriptions of basalt layers suggest variable thickness of units and indicate typical basalt variations of fractured upper and lower crust and more massive interiors along with varying degrees of vesiculation (fig. 2). Detailed lithologic logs and photographs of rock core are provided in appendixes 4-6.

\section{Borehole Geophysical Logs}

Borehole geophysical data were collected on completion of coring using wireline logging tools operated and owned by the USGS INL Project Office. Borehole video files were recorded using wireline camera equipment, also owned and operated by the USGS INL Project Office. The log type, logging tool identifier, logging depth, date and time of log, and sensor uncertainty are provided in table 2 . The USGS calibrates geophysical logging equipment and sensors annually or on an as-needed basis. 


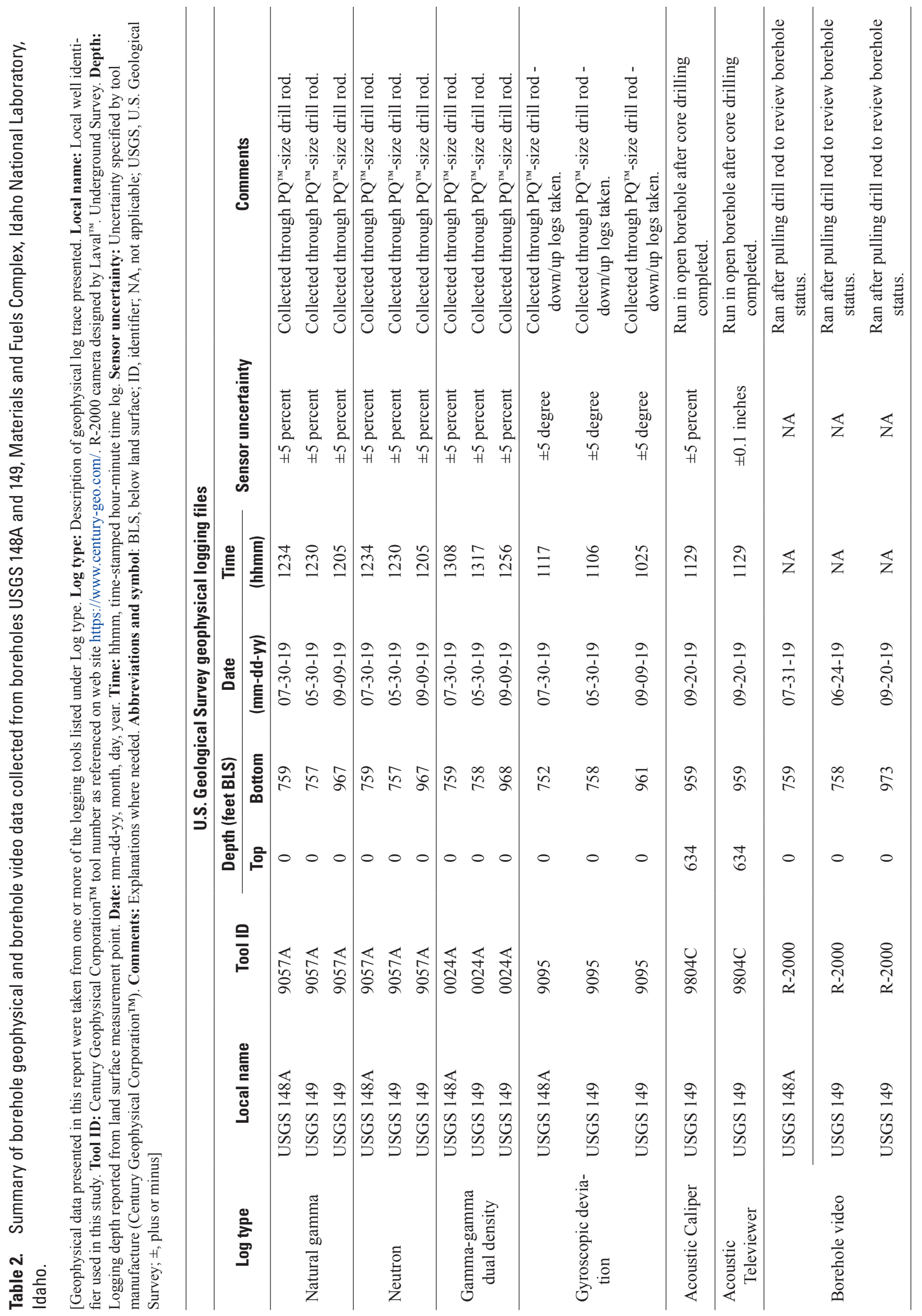




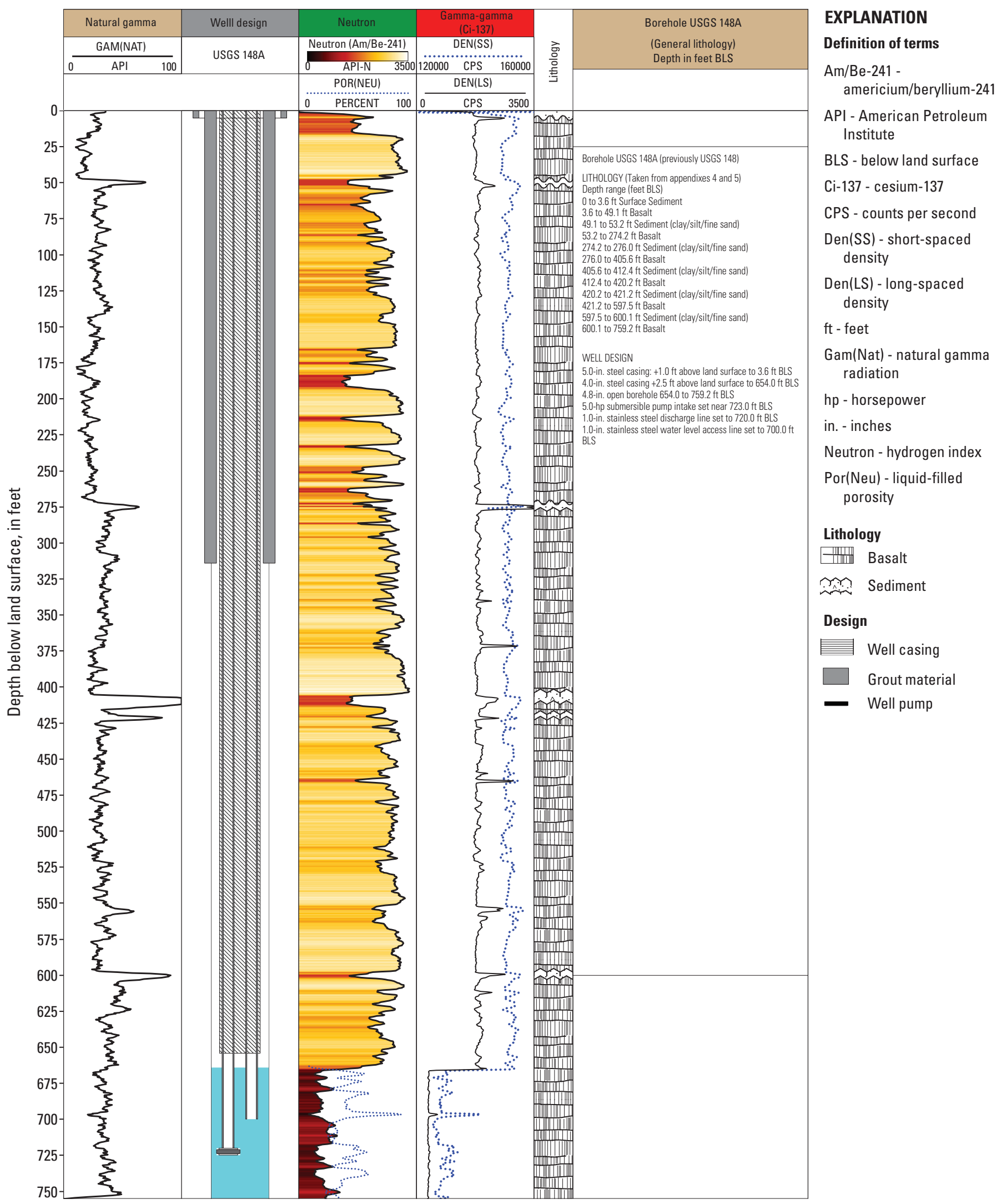

Figure 6. Borehole geophysical logs (including natural gamma, neutron, and gamma-gamma, well design) and generalized lithology described from cores, video logs, and geophysical logs for borehole USGS 148A, Materials and Fuels Complex, Idaho National Laboratory, Idaho. USGS, U.S. Geological Survey. 


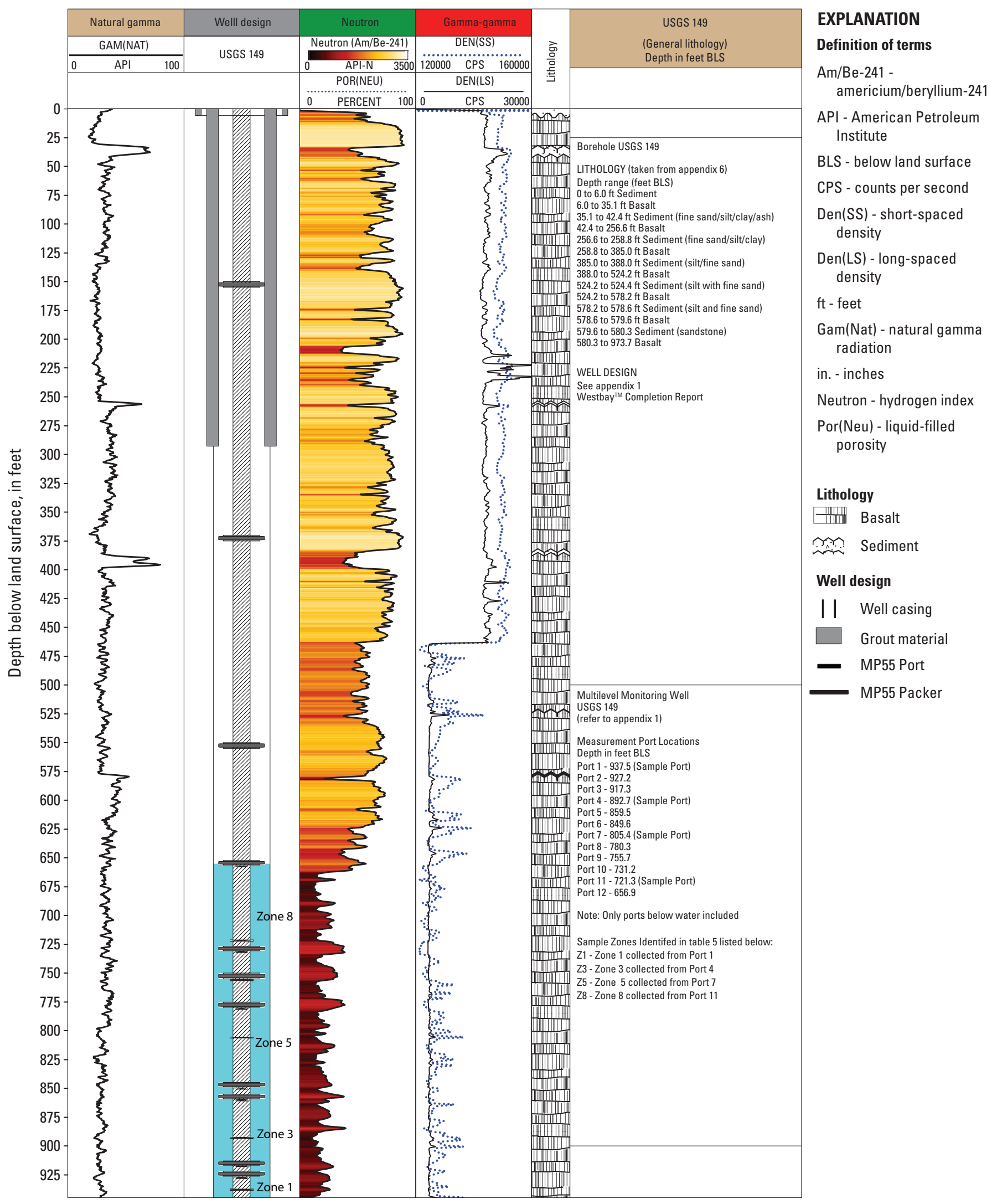

Figure 7. Borehole geophysical logs (including natural gamma, neutron, and gamma-gamma, well design) and generalized lithology described from cores, video logs, and geophysical logs for borehole USGS 149, Materials and Fuels Complex, Idaho National Laboratory, Idaho. USGS, U.S. Geological Survey. 


\section{Natural Gamma Logs}

In this study, the primary use of the natural gamma log was to confirm and compare the location and thickness of sediment layers with lithologic logs presented in appendixes $5-6$. Natural gamma logs record gamma radiation emitted by naturally occurring radioisotopes. The natural gamma detector measures total gamma radiation without distinguishing among individual contributions of the various isotopes. The USGS has used natural gamma logging at the INL to identify sedimentary layers in boreholes, but also to distinguish between basalt flows containing different amounts of potassium- 40 . Most logging tools used by the USGS include a natural gamma detector along with other sensors and detectors. The natural gamma logs shown in report figures are identified in table 2.

Five sediment layers, excluding surface sediment, are described in lithologic logs for borehole USGS 148A (fig. 6; app. 5). The depth and thickness of sediment layers recovered from borehole USGS 148A generally correlated well with natural gamma logs. Sediment layers were relatively thin (less than $7 \mathrm{ft}$ ) and constituted less than 3 percent by volume of the material recovered in borehole USGS 148A. Recovered sediment consisted mostly of fine-grained sand, silt, and some clay.

Six sediment layers, excluding surface sediment, were measured in natural gamma logs of borehole USGS 149 and correlate well to lithologic logs (fig. 7; app. 6). Sediment-layer thickness and depth mostly agreed with the natural gamma log for borehole USGS 149. In certain instances, the thickness of sediment layers in the lithologic log of borehole USGS 149 was overestimated in the natural gamma log. For example, near a depth of $385.0 \mathrm{ft} \mathrm{BLS}$, the lithologic core in appendix 6 suggested that the sediment was about $3.0 \mathrm{ft}$ in thickness; however, the natural gamma log suggested the sediment layer could be $13.0 \mathrm{ft}$ thick. Where lithologic core was recovered for most of this section, the sediment thickness was approximated from lithologic core, not the natural gamma log. Sediment layers measured in borehole USGS 149 were relatively thin (less than $7 \mathrm{ft}$ ) and constituted a small percentage of the material recovered (approximately 2 percent by volume). The sediment recovered consisted mostly of fine-grained sand, silt, and some clay.

\section{Neutron Logs}

Neutron logs are a general indicator of hydrogen content and, when combined with natural gamma logs for sediment location, can be used to identify perched groundwater. The neutron detector continuously records induced radiation produced by bombarding surrounding media (casing, formation, and fluid) with fast neutrons (energies greater than $10^{5}$ electron volts) from a sealed neutron source, which collide with surrounding atomic nuclei until they are captured (Keys, 1990, section 5, p. 95). The neutron probe used by the USGS INL Project Office has an americium/beryllium neutron source and a helium-3 detector that counts slow (thermal) neutrons (those that have energies less than 0.025 electron volts). The neutron logs were collected through drill casing, generally once core drilling was complete.

Neutron logs indicated no evidence of perched groundwater in unsaturated media, located above the water table. Neutron logs for boreholes USGS 148A and 149 (figs. 8-9) also were examined to identify zones of high and low hydrogen content. A color-gradient scale, ranging from red (high hydrogen content) to white (low hydrogen content), was applied to show the location of water-producing zones. The neutron logs correlated well with acoustic televiewer (ATV) logs collected for borehole USGS 149 and lithologic logs collected for boreholes USGS 148A and 149 (figs. 8-9; app. 5-6). Zones with low hydrogen content correlated with dense and massive basalt, whereas zones with high hydrogen content correlated with fractured and vesicular basalt for saturated media.

\section{Gamma-Gamma Dual Density Logs}

Gamma-gamma dual density logging detects Comptonscattered gamma rays that originate from a fully encapsulated, 0.2 -curie cesium-137 source. The radioactive source is threaded into the bottom of the tool during operation, like the neutron source. The source is stored in a shipping container during transport and when not in operation. The intensity of the gamma radiation reflected back to the probe is a function of the electron density of the medium after it is backscattered or absorbed in a drill hole, borehole fluid, or surrounding media. In the study, we used an omni-directional, dual detector sonde that responds to density variation in counts per second (CPS), registering higher CPS counts for lower-density material.

Gamma-gamma dual density data were collected in boreholes USGS 148A and 149 (figs. 6-9; table 2). Gammagamma dual density logs were used to identify areas of unfractured and fractured basalt. The depths of fractured basalt zones, indicated in gamma-gamma dual density logs, correlated well with fractured zones from other geophysical logs in boreholes USGS 148A and 149. 


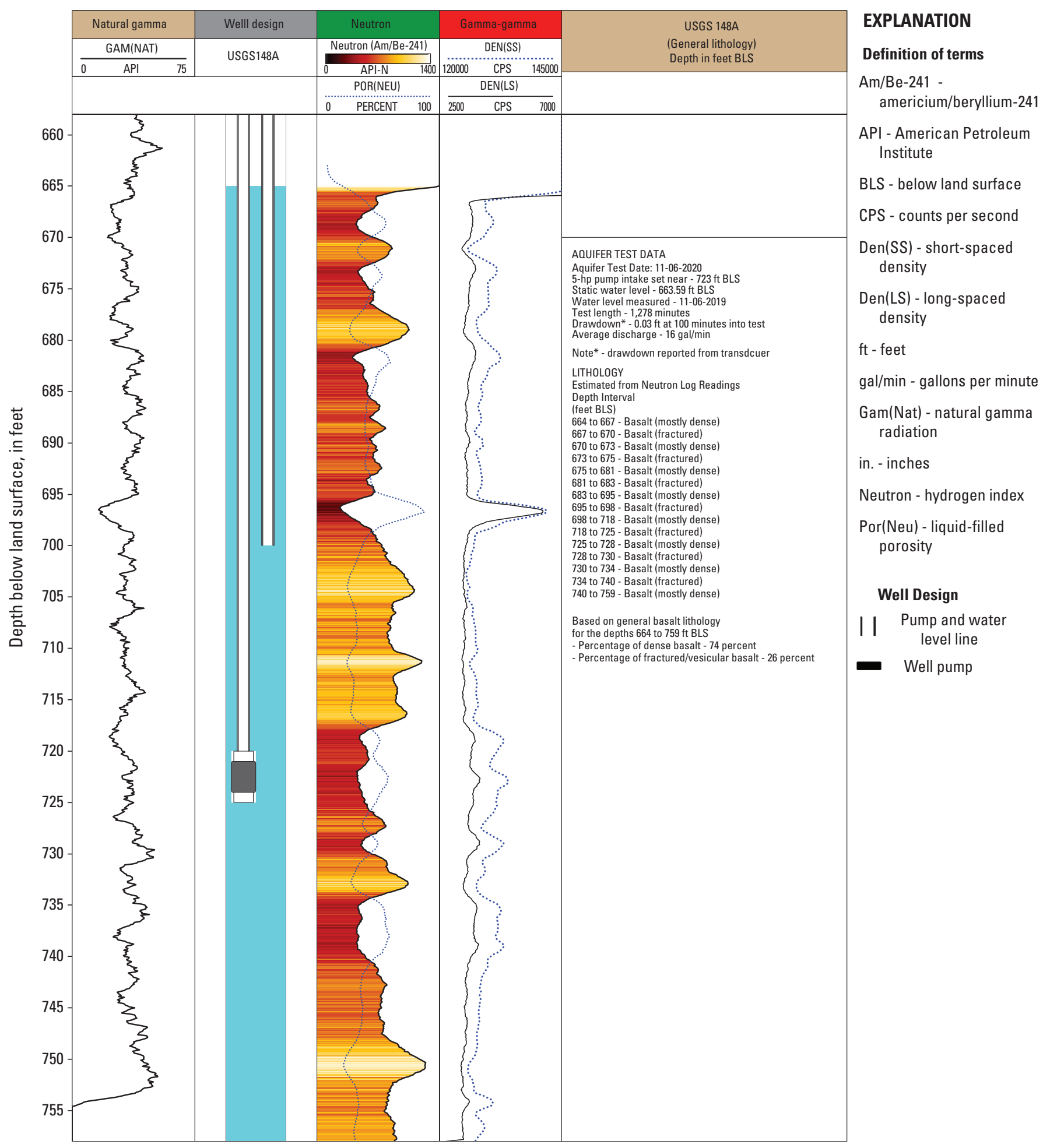

Figure 8. Expanded geophysical and lithologic logs with focus on depths 655-757 feet below land surface for borehole USGS 148A, Materials and Fuels Complex, Idaho National Laboratory, Idaho. USGS, U.S. Geological Survey. 


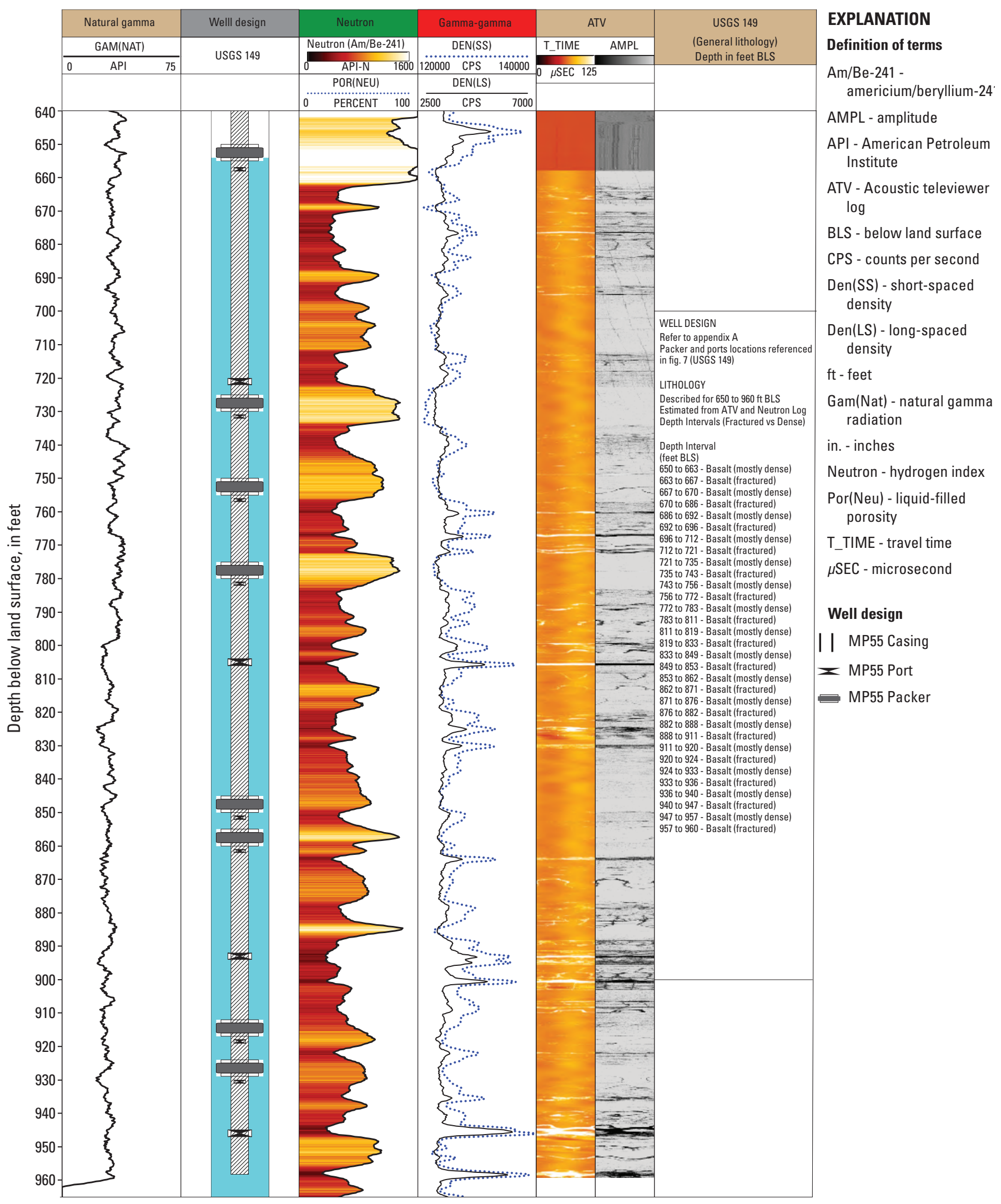

Figure 9. Expanded geophysical and lithologic logs with focus on depths 640-960 feet below land surface for borehole USGS 149, Materials and Fuels Complex, Idaho National Laboratory, Idaho. USGS, U.S. Geological Survey. 


\section{Acoustic Televiewer Logs}

An ATV probe was used in borehole USGS 149 to generate an image of the borehole walls (fig. 9; table 2). Highresolution images are obtained from the ATV probe by rotating a transducer that transmits digital ultrasonic pulses. The transit time (T_Time) and amplitude of the reflected acoustic signal are recorded as photographic-like images. The ATV probe also can be used to collect data in water- or light mud-filled boreholes. Lithologic changes, foliations, bedding planes, and sealed fractures may be detected even when there is no change in the borehole diameter if there is sufficient acoustic contrast (Williams and Johnson, 2004). The ATV and neutron logs are shown together to indicate the location of fractures, relative fracture density, and fracture thickness (fig. 9). A detailed analysis of fracture orientation and aperture was not completed in this report.

Centralizers were attached to the ATV probe to center the probe inside the open borehole. The ATV probe recorded data for the saturated section of the cored borehole. The borehole diameter (4.8 in.) was adequate for the ATV probe as it was within the suggested diameter range of 2.9-9.0-in. (Williams and Johnson, 2004). To maximize the image quality, the ATV probe was trolled upward at 3-4 feet per minute with the data collection interval set at $0.02 \mathrm{ft}$ per measurement. The ATV image data for borehole USGS 149 seem to correlate well with neutron logs shown in fig. 9. Basalt flow contacts and areas of dense basalt were well imaged for the section from 655.0 to $959.0 \mathrm{ft}$ BLS in borehole USGS 149. The ATV image data display dense and lightly fractured basalt intervals that were also used to determine the location for packers prior to installation of the multilevel monitoring system (fig. 9).

\section{Gyroscopic Deviation Survey}

A borehole gyroscopic deviation survey was completed for boreholes USGS 148A and 149 to determine well bore deviations and the projected well bore path (fig. 10). The gyroscopic deviation survey procedure and equations used to compute calculated offset, northing, easting, distance, and azimuth are described in Twining (2016). Gyroscopic deviation data were continuously collected at regularly spaced intervals of $0.2 \mathrm{ft}$ and processed using the software supplied by the tool manufacture.

Gyroscopic deviation data for boreholes USGS 148A and 149 are shown in 100-ft increments (table 3; fig. 10). The calculated offset accounts for horizontal and vertical displacements at various depths for each borehole (table 3); however, the calculated offset near the approximate depth to water was $0.19 \mathrm{ft}$ in borehole USGS $148 \mathrm{~A}$ and $0.11 \mathrm{ft}$ in borehole USGS 149 (table 3). A water-level correction is required when the gyroscopic deviation survey calculates an offset exceeding $0.20 \mathrm{ft}$ (Twining, 2016). No water-level correction was necessary for borehole USGS 148A or USGS 149 because the offset in both boreholes was less than $0.20 \mathrm{ft}$. Details of the gyroscopic deviation survey data are presented in 50-ft increments near the estimated depth to water and near the total completion depth (table 3). 


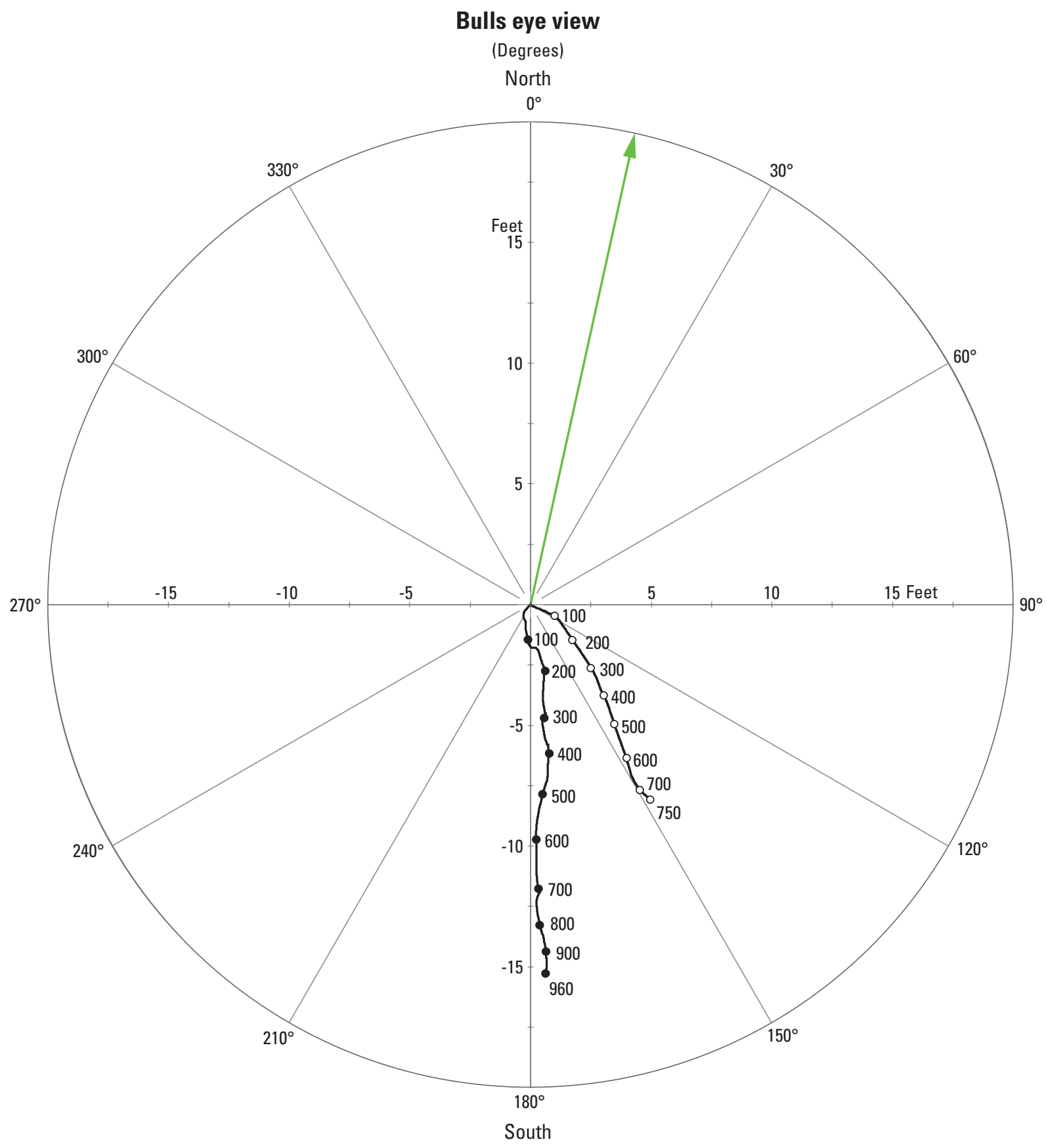

EXPLANATION

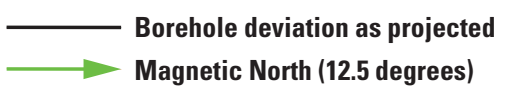

○ Borehole USGS 148A gyro deviation measurement at 100 -foot increments

- Borehole USGS 149 gyro deviation measurement at 100 -foot increments

Figure 10. Gyroscopic deviation survey data for boreholes USGS 148A and 149 plotted as profiles in a bull's-eye view that shows horizontal offset and direction, Materials and Fuels Complex, Idaho National Laboratory, Idaho. USGS, U.S. Geological Survey. 
Table 3. Gyroscopic deviation survey data shown in 50-foot increments for boreholes USGS 148A and 149, Materials and Fuels Complex, Idaho National Laboratory, Idaho.

[Borehole deviation profile is shown in figure 10. Open (USGS 148A) and solid black (USGS 149) circles represent measurements taken at 50-foot increments. Survey was done using a Century Geophysical Corporation ${ }^{\mathrm{TM}} 9095$ logging tool with magnetic declination was set at constant 12.5 degrees. Local name is the local well identifier used in this study. CD (cable depth) is reported from wireline depth. TVD (true vertical depth) is computed depth using average angles equation (Twining, 2016). CO (calculated offset) is computed (CD-TVD). Northing, Easting, Distance, and Azimuth are computed from the well path survey using SANG and SANGB data. Abbreviations: BLS, below land surface; ft, feet; deg, degrees; SANG, inclination or slant angle; SANGB, azimuth or slant angle bearing from well survey; USGS, U.S. Geological Survey]

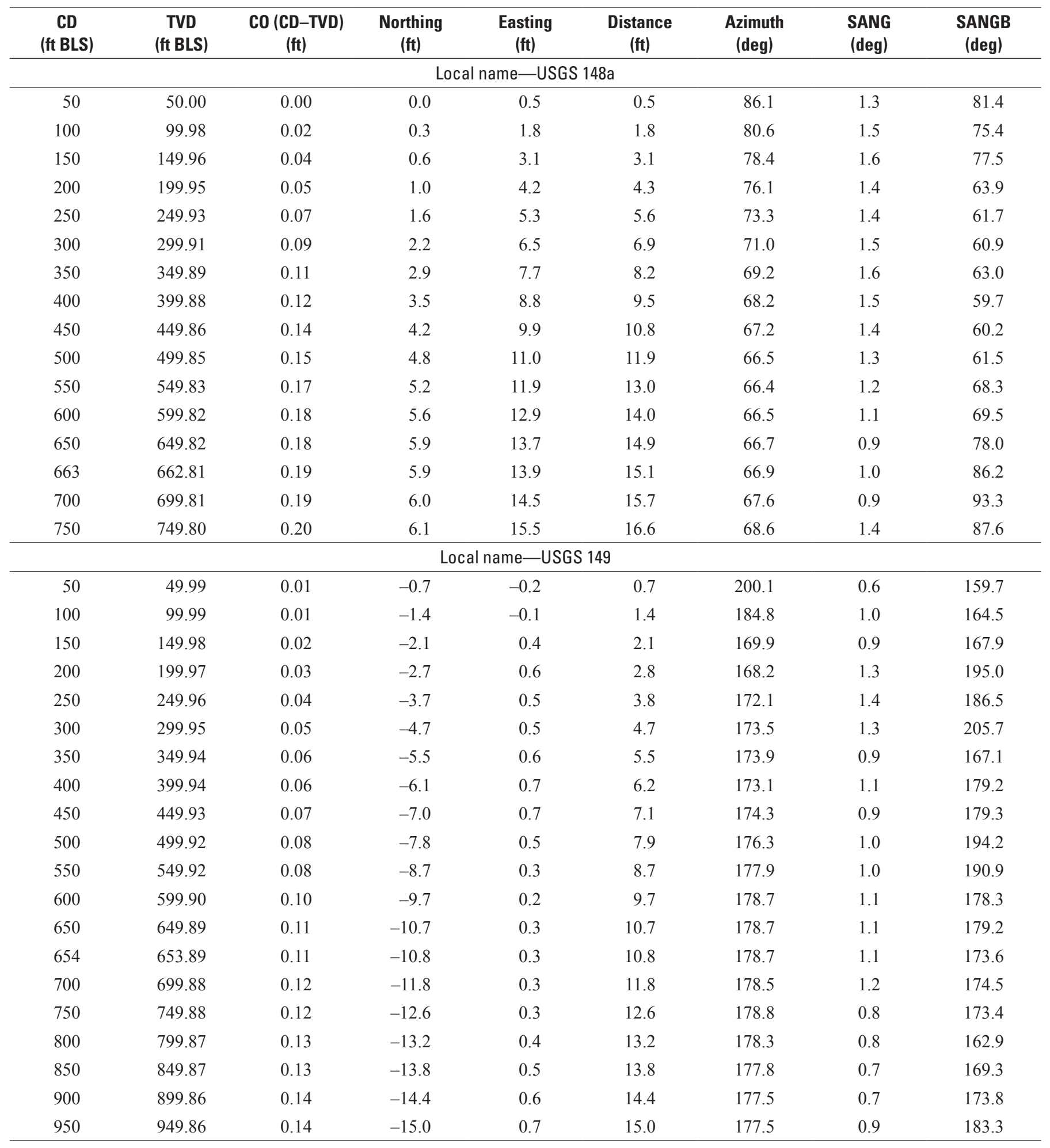




\section{Single-Well Aquifer Test}

A single-well aquifer test was completed during November 6-7, 2019, in monitoring well USGS 148A. Well USGS 148A was pumped continuously for about 21.3 hours (1,279 minutes), starting at 1300 hours on November 6, 2019, and ending at 1020 hours on November 7, 2019. The final construction for well USGS 148A includes a 4.8-in.-diameter open hole, extending from 654 to $759 \mathrm{ft}$ BLS with partial penetration of the ESRP aquifer (figs. 4, 8). Geophysical and lithologic logging records for well USGS 148A (fig. 8) indicate a complex fractured basalt stratigraphy. Primary flow paths for groundwater are thought to occur along intervals of fractured and vesicular basalt starting near 667, 673, 681, 695, 718,728 and $734 \mathrm{ft}$ BLS, with little to no flow within dense basalt intervals.

\section{Single-Well Aquifer Test Procedures}

During the single-well aquifer test in the well USGS 148A fluid pressure head, barometric pressure, fluid temperature, and air temperature were measured continuously over 1-minute intervals. The fluid pressure heads, $\Psi_{w+a t m}$, and fluid temperature were measured using a self-contained datalogger suspended on a direct read cable. The datalogger was placed inside a 1-in. SS water-level line the day before testing started and was submersed about $20 \mathrm{ft}$ below the water table (figs. $11,12 A)$. The datalogger deployed for the single-well aquifer test was the Model 3001 Solinst $^{\circledR}$ Levelogger ${ }^{\circledR}$, F65/M20, with full-scale range specified at $65.5 \mathrm{ft}$ and a stated accuracy of plus or minus ( \pm ) $0.03 \mathrm{ft}$. The barometric pressure, $\Psi_{\text {atm }}$, and air temperature were measured using a self-contained atmospheric pressure and temperature datalogger suspended inside the casing, about $8 \mathrm{ft}$ down the well (figs. 11, 12B). The barologger deployed for the aquifer test was the Model 3001 Solins $\mathrm{t}^{\mathbb{B}}$ Barologger ${ }^{\mathbb{B}}, \mathrm{F} 5 / \mathrm{M} 1.5$, with an operating temperature range of -20-80 degrees Celsius and stated accuracy of \pm 0.01 pounds per square inch.

The compensated fluid pressure head, $\Psi$, was obtained by subtracting the fluid pressure head, $\Psi_{\mathrm{w}+\mathrm{atm}}$, from the barometric pressure, $\Psi_{\text {atm, }}$ (eq. 1). Compensated fluid pressure head computation was done using the software provided by Solinst ${ }^{\mathbb{R}}$ and calculated using the following equation (fig. 12A):

$$
\psi=\psi_{w+a t m}-\psi_{\text {atm }}
$$

$$
\begin{aligned}
\text { where } & \text { is the compensated fluid pressure head, } \\
\Psi & \text { is the fluid pressure head, and } \\
\Psi_{\mathrm{w}^{+}+\mathrm{atm}} & \text { is the barometric pressure. }
\end{aligned}
$$

Manual water-level measurements were collected using an electric tape during the early and late part of the pumping test. The electric tape probe was lowered down the same 1-in. SS measurement line as the datalogger used to measure fluid pressure head (fig. 11). The manual water-level measurements were not collected throughout the entire test, but attempts were made to collect early and late time measurements as time permitted to supplement compensated fluid pressure readings. Compensated fluid pressure readings after the submersible pump was turned off (recovery data) were collected but not analyzed. Additionally, no manual water-level measurements were collected after the pump was turned off.

The flow rate, $Q$, associated with well discharge was monitored periodically using a Blue White ${ }^{\circledR}$ F-2000 paddlewheel flowmeter sensor (figs. 11, 13). Measurements were collected manually using a bucket and stopwatch during the first 10 minutes of testing because of a stopwatch malfunction in the flow sensor. However, the flowmeter was restarted 13 minutes into the single-well aquifer test and used to report the flow rate, $Q$, during the remainder of the test (fig. 13). Measured flow rates remained relatively constant throughout the test, averaging 16.0 gallons per minute (gal $/ \mathrm{min}$ ) or 2.14 cubic feet per minute. Measured discharges ranged from 15.7 to $16.1 \mathrm{gal} / \mathrm{min}$ (fig. 13). Purge water generated during the pumping test was discharged to the ground.

\section{Analysis of Single-Well Aquifer Test Data}

Single-well aquifer test results from monitoring well USGS 148A were analyzed using the Cooper-Jacob method of curve fitting (Cooper and Jacob, 1946) to estimate transmissivity. The Cooper-Jacob method (Cooper and Jacob, 1946), a simplification of the Theis solution, assumes that the pumping well fully penetrates a confined, homogeneous, and isotropic aquifer of infinite extent. Hydrologic conditions at well USGS 148A depart greatly from the Theis (1935) model given that the well partially penetrates an unconfined heterogeneous anisotropic aquifer. The Cooper-Jacob method was used, regardless of the differences between field conditions and theory, for its simplicity. In an analysis of single-well tests, Halford and others (2006) reported that the Cooper-Jacob method (Cooper and Jacob, 1946) is well-suited for estimating hydraulic properties.

The Cooper-Jacob method (Cooper and Jacob, 1946) estimates transmissivity by fitting a straight line to water-level drawdown measurements on a linear y-axis compared to time on a logarithmic $\mathrm{x}$-axis. Transmissivity, $\mathrm{T}$, is determined from the slope of the straight line using the following equation:

$$
T=\frac{2.3 Q}{4 \pi} \frac{1}{\Delta s}
$$

where

$Q \quad$ is the pumping rate, and

$\Delta s \quad$ is the log cycle drawdown. 


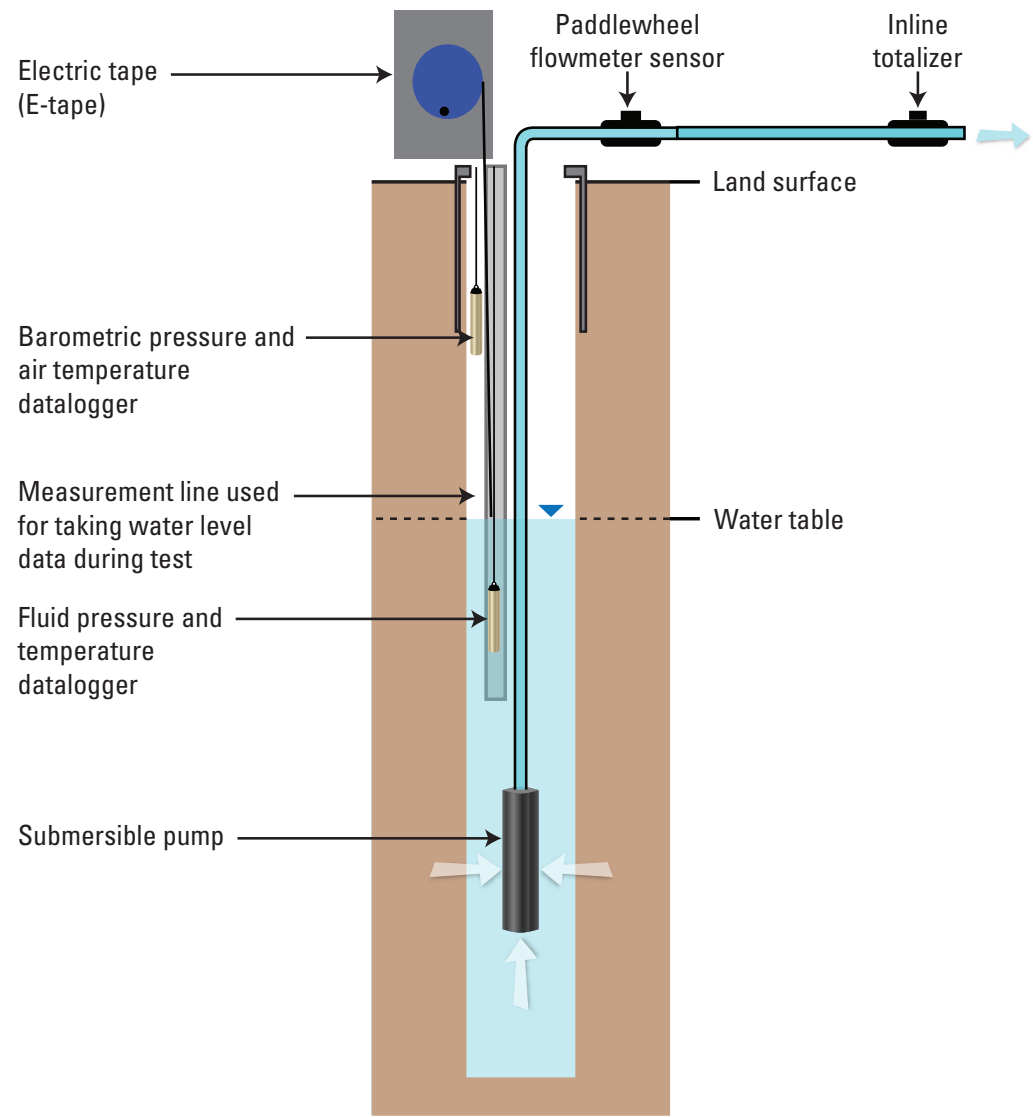

Figure 11. Idealized schematic showing pressure sensor and pump placement during the single-well aquifer test at well USGS 148A, Materials and Fuels Complex, Idaho National Laboratory, Idaho (modified from Twining and others, 2014). 

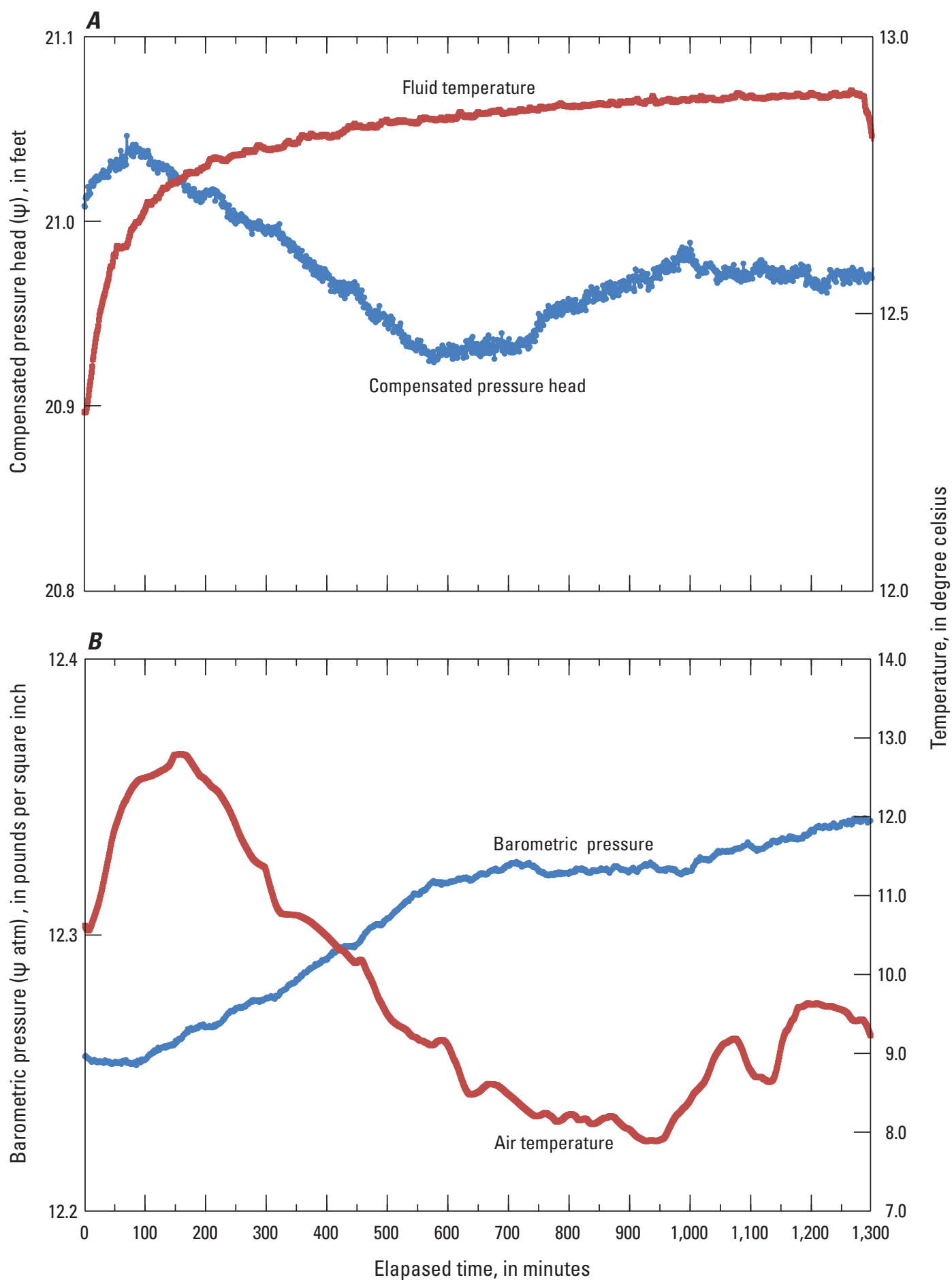

Figure 12. Changes in $(A)$ compensated pressure head and fluid temperature, and $(B)$ barometric pressure and air temperature through time, during the single-well aquifer test in well USGS 148A, Materials and Fuels Complex, Idaho National Laboratory, Idaho, November 6-7, 2019. 


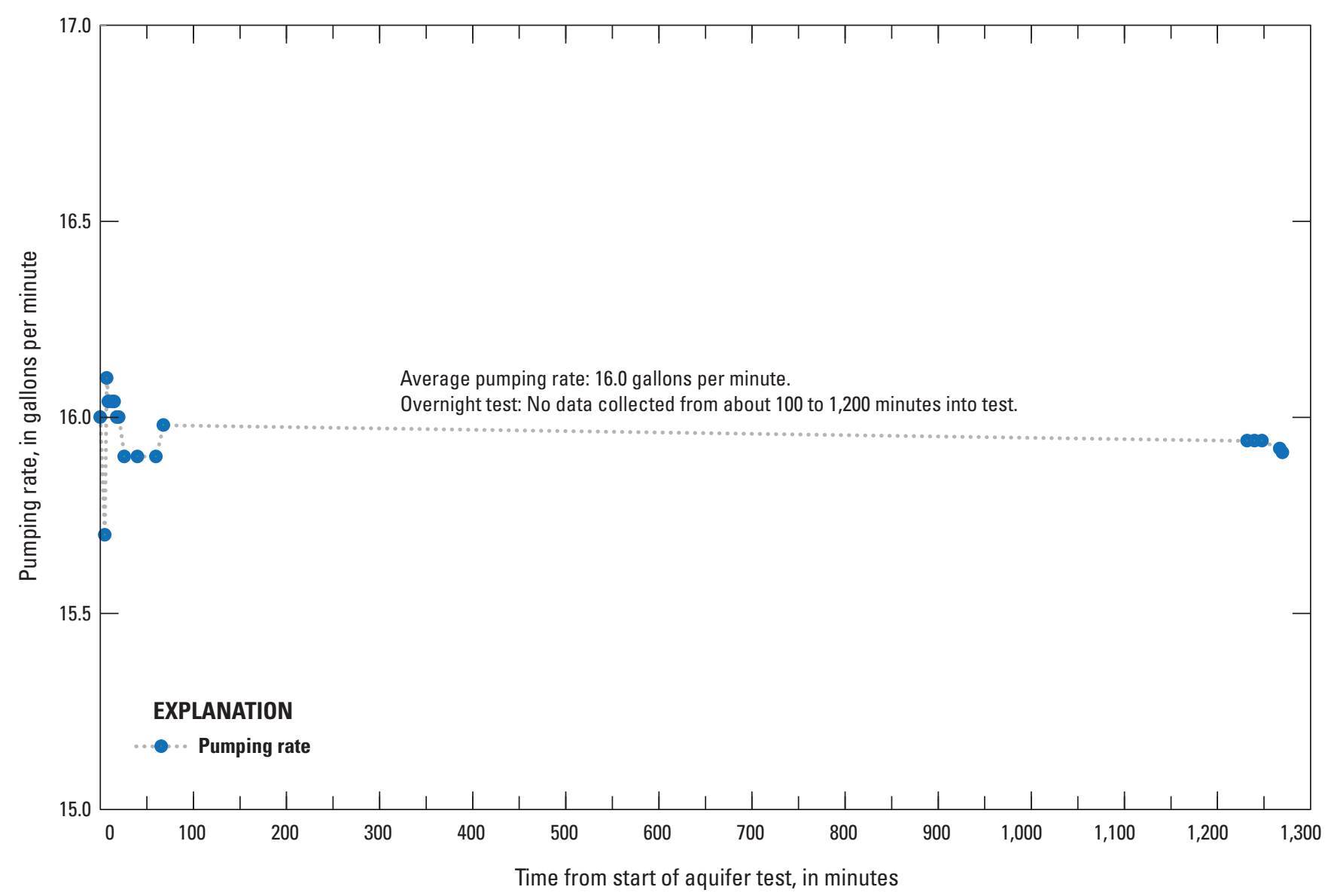

Figure 13. Measured pumping rates during the single-well aquifer test at well USGS 148A, Materials and Fuels Complex, Idaho National Laboratory, Idaho, November 6-7, 2019.

The drawdown in the well, $s$, at any given time, $t$, is determined by subtracting the pressure head at time $t$ from the initial pressure head prior to pumping, $\Psi_{0}$. Drawdown as a function of time was calculated using the following equation:

$$
s(t)=\psi_{0}-\psi(t) .
$$

Hydraulic conductivity was estimated using the aquifer thickness from table 1 rather than the tested water column length (table 1). Halford and others (2006) reported that, in most instances, dividing the total estimated aquifer thickness produced more realistic transmissivity estimates than water column length for unconfined aquifers with partial penetration. The hydraulic conductivity was calculated using the following equation:

$$
K=\frac{T}{b}
$$

where

$K \quad$ is the hydraulic conductivity,

$T$ is the transmissivity, and

$b \quad$ is the aquifer thickness.

\section{Hydraulic Property Estimates}

Hydraulic properties, transmissivity, and hydraulic conductivity were estimated for the single-well aquifer test at well USGS 148A. To estimate drawdown that occurred during the test, manual water-level measurements and compensated fluid pressure measurements taken from 250 to 650 minutes into the test were considered. The manual water-level measurements show an estimated drawdown ( $\Delta s)$ of $0.09 \mathrm{ft}$ (fig. 14). The measured water-level collected during the test ranged from $663.59 \mathrm{ft}$ BLS before the single-well test started to $663.68 \mathrm{ft}$ BLS at 1,278 minutes into test. Manual water-level measurements suggest the water levels mostly were stable after about the first 15 minutes (fig. 14).

Compensated fluid pressure measurements, shown as drawdown, indicated early and late time drawdown irregularities for well USGS 148A (figs. 12A, 14). Compensated fluid pressure readings indicate a water-level rise during the first 250 minutes (early time data), water-level decline from 250 to 650 minutes, and water-level rise again after 650 minutes (late time data) into the single-well aquifer test. Early and late time compensated fluid pressure readings were ignored and disagreed with manual measurement data collected; however, 


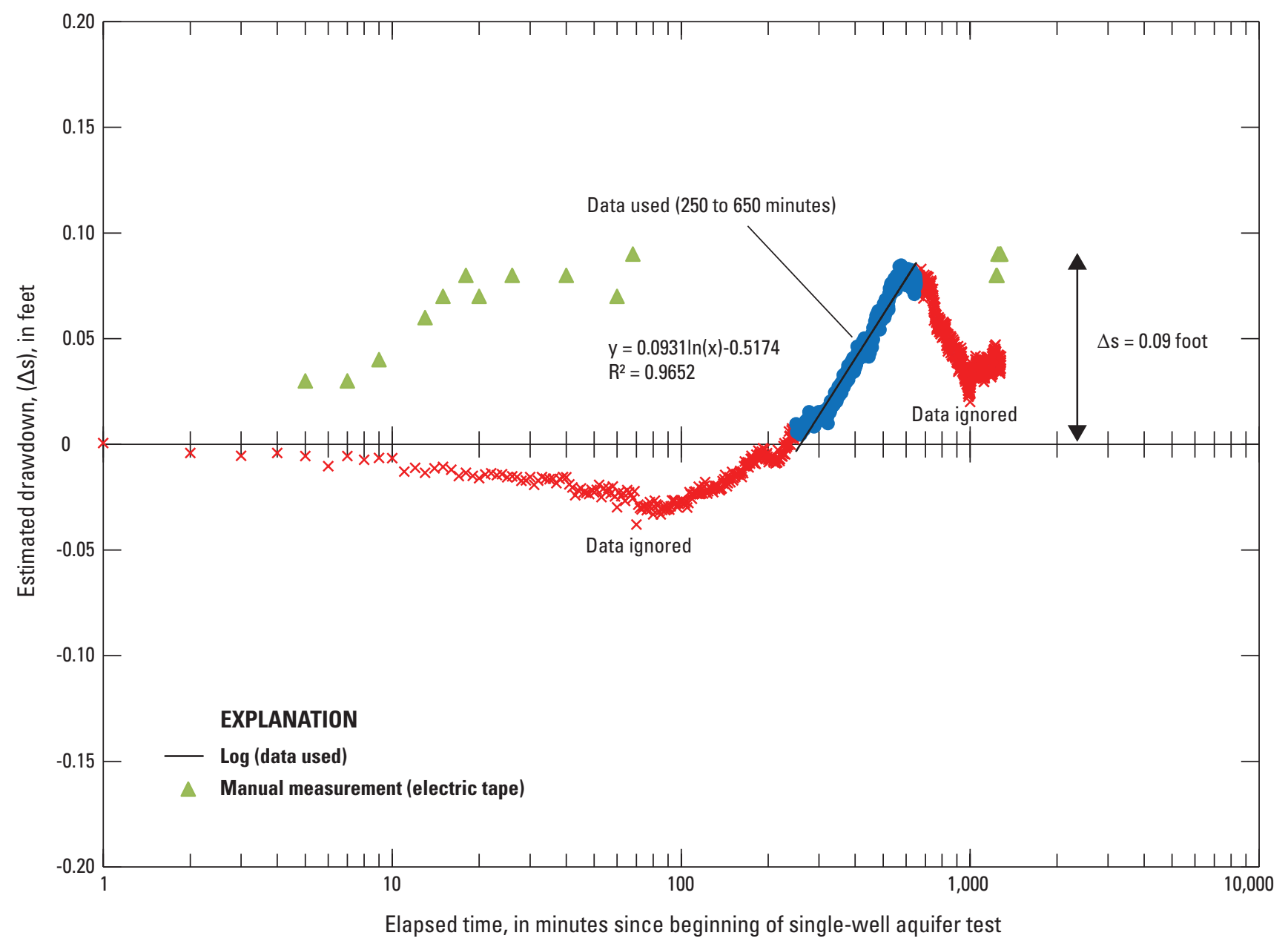

Figure 14. Single-well aquifer test drawdown, represented as compensated fluid pressure and manual water-level measurements over time collected for well USGS 148A, Materials and Fuels Complex, Idaho National Laboratory, Idaho, November 6-7, 2019. R², coefficient of determination.

compensated fluid pressure readings for this study assume a barometric efficiency of 100 percent and likely do not accurately represent the actual fluid pressure response to barometric pressure. The general response to increased barometric pressure is a water-level decline and the opposite is true when a decrease in barometric pressure is measured. A better estimate of barometric efficiency is required to better understand the compensated fluid pressure response when early and late time data are ignored, but this estimate was not made as part of this study. Instead, the estimated drawdown was considered using manual measurement data and select compensated fluid pressure readings. This approach was not ideal, but it provided a reasonable solution to this complex dataset where the overall water-level response to pumping was minimal. Approximately $0.09 \mathrm{ft}$ of drawdown occurred in well USGS 148 over 400 minutes (250-650 minutes) (fig. 14). Taking into consideration reported drawdown of less than $0.10 \mathrm{ft}$, the stated accuracy of the pressure transducer $( \pm 0.03 \mathrm{ft})$, and the barometric effect on water levels over the testing period, the reported drawdown $(\Delta s)$ of $0.09 \mathrm{ft}$ is considered reasonable (fig. 14).

Given the limitations of the data collected, the CooperJacob method was used to approximate transmissivity. Not all data were honored and only select data were used to fit the semilog slopes. The estimated Cooper-Jacob transmissivity considered the change in drawdown $(\Delta s)$ over a partial log cycle (250-650 minutes), but also considered agreement with manual water-level measurements.

The Cooper-Jacob method (Cooper and Jacob, 1946) was applied to the aquifer test data in figure 14. Transmissivity and hydraulic conductivity were estimated at $6.34 \times 10^{3} \mathrm{ft}^{2} /$ day and 3.17 feet per day (ft/day), respectively. An aquifer thickness of $2,000 \mathrm{ft}$ was selected to estimate hydraulic conductivity, which was based on the bottom of the aquifer as interpreted from 
geophysical surveys (Whitehead, 1992; Ackerman and others, 2010). Calculations of these two parameters (eqs. 2 and 4) are shown as follows:

$$
\begin{aligned}
& T=\frac{2.3 Q}{4 \pi} \frac{1}{\Delta s}=\frac{2.3 \times 2.14 \mathrm{ft}^{3} / \mathrm{min}}{4 \pi \times 0.09 \mathrm{ft}^{2}} \\
& =4.4 \mathrm{ft}^{2} / \mathrm{min} \text { or } 6.34 \times 10^{3} \mathrm{ft}^{2} / \mathrm{day} \\
& K=\frac{T}{b}=\frac{4.4 \mathrm{ft}^{2} / \mathrm{min}}{2000 \mathrm{ft}} \\
& =2.2 \times 10^{-3} \mathrm{ft} / \mathrm{min} \text { or } 3.17 \mathrm{ft} / \mathrm{day}
\end{aligned}
$$

A comparison of transmissivity values calculated for well USGS 148A and values determined from previous aquifer tests at two wells near well USGS 148A suggests reasonable agreement (fig. 1; table 4). Aquifer test data near well USGS 148A show transmissivity ranges from $1.4 \times 10^{4}$ to $5.6 \times 10^{5} \mathrm{ft}^{2} /$ day, based on two test values (Ackerman, 1991). The estimated transmissivity for well USGS 148A was slightly lower than other wells presented in table 4 , but within a reasonable range presented for other aquifer tests done at the INL (Ackerman, 1991; Twining and Maimer, 2019). The average USGS 148A hydraulic conductivity value was well within the range of values reported in the literature for similar rock types; Freeze and Cherry (1979) reported hydraulic-conductivity values for permeable basalt ranging from $5.7 \times 10^{-2}$ to $5.7 \times 10^{3} \mathrm{ft} /$ day. The hydraulic conductivity of the ESRP aquifer at or near the INL ranged from about $1.0 \times 10^{-2}$ to $3.2 \times 10^{4} \mathrm{ft} / \mathrm{day}$ (Anderson and others, 1999).

\section{Water-Quality Sample Collection}

\section{Sample Collection Methods}

Water-quality samples were collected during November 4-5, 2019, from well USGS 149 and on November 7, 2019, from USGS 148A (table 5) after the wells were purged for about 21 hours and stable readings of $\mathrm{pH}$, water temperature, and specific conductance were recorded. Water-quality samples were collected from four multilevel monitoring ports, located within discrete zones, in well USGS 149 (app. 1). Water-quality samples were collected from a 0.25 -in. diameter SS sample port at USGS 148A, which was installed from piping at the wellhead after the well was purged with a submersible pump and field measurements were stable. The constituents sampled after well completion were selected to provide a characterization of baseline water chemistry and radionuclide concentrations. Field measurements of water and air temperature, $\mathrm{pH}$, specific conductance, dissolved oxygen, and alkalinity were collected prior to sampling (table 5). Samples from select zones within well USGS 149 were collected from 4 separate ports by lowering pre-cleaned SS sample bottles to each zone and filling and then processing them as described in Bartholomay and others (2014, p 15).

Water-quality sample collection at well USGS 148A and 149 generally followed guidelines documented in the USGS National Field Manual for the Collection of WaterQuality Data (U.S. Geological Survey, variously dated) and Bartholomay and others (2014). Water-quality samples were processed in the field according to protocols for the constituents for which analyses were requested. Samples to be analyzed for chemical constituents by the USGS National Water Quality Laboratory (NWQL) were placed in containers and preserved in accordance with laboratory requirements specified by Bartholomay and others (2014, appendix A). Containers and preservatives were supplied by the NWQL and underwent rigorous quality-control procedure (Pritt, 1989, p. 75) to minimize sample contamination. Samples requiring field filtration were filtered through a disposable 0.45 -micrometer cartridge pre-rinsed with at least 2 liters of deionized water. Water samples analyzed for radionuclides were placed in containers and preserved in accordance with laboratory requirements specified by Bodnar and Percival (1982) and Bartholomay and others (2014, appendix A) prior to being sent to the Radiological and Environmental Sciences Laboratory (RESL) at the INL. Water samples for stable isotopes of oxygen and hydrogen were collected in bottles provided by the NWQL and shipped to the USGS Reston Stable Isotope Laboratory (RSIL)-Isotope Fractionation Project in Reston, Virginia, for analysis. The samples for uranium isotopes were collected in bottles provided by the NWQL and shipped to Australian Laboratory Services Environmental in Fort Collins, Colorado. Water samples for tritium were collected in bottles provided by the NWQL and shipped to the USGS Menlo Park Research Laboratory for analyses.

Table 4. Comparison of transmissivity values estimated from aquifer tests done at wells near USGS 148A, Materials and Fuels Complex, Idaho National Laboratory, Idaho.

[Locations of wells are shown in figure 1. Local name: Local well identifier used in this study. Site identifier: Unique numerical identifiers used to access well

\begin{tabular}{|c|c|c|c|c|c|}
\hline Local name & Site identifier & Longitude & Latitude & $\begin{array}{c}\text { Transmissivity } \\
\left(\mathrm{ft}^{2} / \mathrm{d}\right)\end{array}$ & $\begin{array}{l}\text { Distance to } \\
\text { USGS } 148 \text { (mi) }\end{array}$ \\
\hline Arbor Test & 433509112384801 & $112^{\circ} 38^{\prime} 48.01^{\prime \prime}$ & $43^{\circ} 35^{\prime} 08.92^{\prime \prime}$ & $5.6 \times 10^{5}$ & 0.6 \\
\hline
\end{tabular}
data (U.S. Geological Survey, 2021). Latitude and Longitude: In degrees, minutes, and seconds based on the North American Datum of 1983. Transmissivity: Values are from aquifer tests presented in Ackerman (1991). Distance to USGS 148A: Straight-line distance within the aerial dimension to the USGS 148A well. Abbreviations: USGS, U.S. Geological Survey; $\mathrm{ft}^{2} / \mathrm{d}$; feet squared per day; mi, mile] 
Table 5. Concentrations of selected chemical and radiochemical constituents in water from well USGS 148A and select zones from multilevel well USGS 149, Materials and Fuels Complex, Idaho National Laboratory, Idaho, November 4-7, 2019.

[See figure 1 for well location and figure 5 for multilevel well USGS 149 zones (Z1, Z3, Z5, and Z8) with data access through the National Water Information System (U.S. Geological Survey, 2021). Dates are in mm-dd-yyyy format, indicating month, day, year. Analytical results are in micrograms per liter unless noted otherwise. Bicarbonate data were calculated from alkalinity field measurements—alkalinity divided by 0.8202 (Hem, 1989, p. 57). Samples were analyzed at the USGS National Water Quality Laboratory in Lakewood, Colorado, unless otherwise indicated. Uncertainty of radiochemical constituents is 1 times the estimated sample standard deviation ( $1 \mathrm{~s}$ ). Uncertainty of deuterium and oxygen-18 is \pm 1.5 per mil. Concentrations that met or exceeded the reporting level of 3 times the $1 s$ value are shown in boldface type. Abbreviations and symbols: $\mathrm{CaCO}_{3}$, calcium carbonate; $\mathrm{CFC}$, chlorofluorocarbon; Menlo, USGS Menlo Park Tritium Laboratory, California; MTBE, methyl tert-butyl ether; N, nitrogen; P, phosphorus; RESL, Radiological and Environmental Sciences Laboratory; RSIL, USGS Reston Stable Isotope Laboratory, Virginia; USGS, U.S. Geological Survey; deg ${ }^{\circ} \mathrm{C}$, degrees Celsius; $\mu \mathrm{S} / \mathrm{cm}$, microsiemens per centimeter; mg/L, milligrams per liter; NTU, nephelometric turbidity units; $\mathrm{pCi} / \mathrm{L}$, picocuries per liter; NA, not applicable; <, less than; \pm , plus or minus]

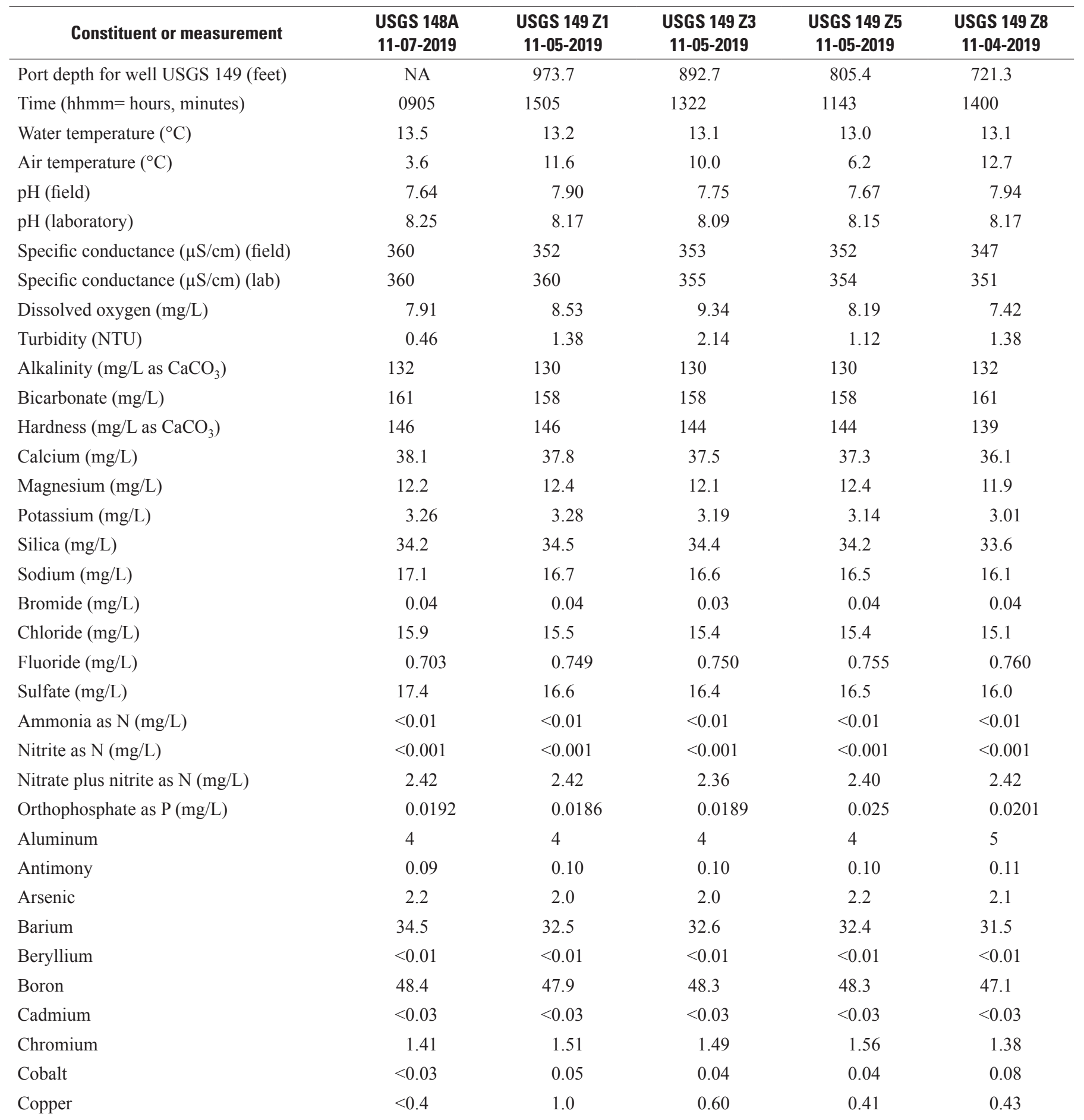


Table 5. Concentrations of selected chemical and radiochemical constituents in water from well USGS 148A and select zones from multilevel well USGS 149, Materials and Fuels Complex, Idaho National Laboratory, Idaho, November 4-7, 2019.—Continued

[See figure 1 for well location and figure 5 for multilevel well USGS 149 zones (Z1, Z3, Z5, and Z8) with data access through the National Water Information System (U.S. Geological Survey, 2021). Dates are in mm-dd-yyyy format, indicating month, day, year. Analytical results are in micrograms per liter unless noted otherwise. Bicarbonate data were calculated from alkalinity field measurements - alkalinity divided by 0.8202 (Hem, 1989, p. 57). Samples were analyzed at the USGS National Water Quality Laboratory in Lakewood, Colorado, unless otherwise indicated. Uncertainty of radiochemical constituents is 1 times the estimated sample standard deviation $(1 \mathrm{~s})$. Uncertainty of deuterium and oxygen-18 is \pm 1.5 per mil. Concentrations that met or exceeded the reporting level of 3 times the $1 s$ value are shown in boldface type. Abbreviations and symbols: $\mathrm{CaCO}_{3}$, calcium carbonate; $\mathrm{CFC}$, chlorofluorocarbon; Menlo, USGS Menlo Park Tritium Laboratory, California; MTBE, methyl tert-butyl ether; N, nitrogen; P, phosphorus; RESL, Radiological and Environmental Sciences Laboratory; RSIL, USGS Reston Stable Isotope Laboratory, Virginia; USGS, U.S. Geological Survey; deg ${ }^{\circ} \mathrm{C}$, degrees Celsius; $\mu \mathrm{S} / \mathrm{cm}$, microsiemens per centimeter; mg/L, milligrams per liter; NTU, nephelometric turbidity units; pCi/L, picocuries per liter; NA, not applicable; <, less than; \pm , plus or minus]

\begin{tabular}{|c|c|c|c|c|c|}
\hline Constituent or measurement & $\begin{array}{l}\text { USGS 148A } \\
11-07-2019 \\
\end{array}$ & $\begin{array}{c}\text { USGS } 149 \text { Z1 } \\
11-05-2019\end{array}$ & $\begin{array}{c}\text { USGS } 149 \text { Z3 } \\
11-05-2019\end{array}$ & $\begin{array}{c}\text { USGS } 149 \text { Z5 } \\
11-05-2019\end{array}$ & $\begin{array}{c}\text { USGS } 149 \text { Z8 } \\
11-04-2019\end{array}$ \\
\hline Iron & $<10$ & $<10$ & $<10$ & $<10$ & $<10$ \\
\hline Lithium & 20.0 & 21.5 & 21.8 & 21.6 & 21.2 \\
\hline Manganese & $<0.4$ & 0.5 & $<0.4$ & $<0.4$ & $<0.4$ \\
\hline Nickel & 0.29 & 0.42 & 0.32 & 0.30 & 0.30 \\
\hline Selenium & 0.42 & 0.44 & 0.45 & 0.40 & 0.39 \\
\hline Silver & $<1$ & $<1$ & $<1$ & $<1$ & $<1$ \\
\hline Strontium & 134 & 128 & 128 & 128 & 121 \\
\hline Vanadium & 5.5 & 5.2 & 5.2 & 5.4 & 5.3 \\
\hline Zinc & 2 & 4 & 5 & 3 & 4 \\
\hline Tritium (pCi/L) (Menlo) & $9.68 \pm 1.03$ & $8.91 \pm 0.94$ & $6.30 \pm 0.93$ & $8.05 \pm 0.93$ & $10.8 \pm 1.03$ \\
\hline Strontium-90 (pCi/L) (RESL) & $1.8 \pm 0.9$ & $1.7 \pm 1.0$ & $1.8 \pm 0.9$ & $1.3 \pm 1.0$ & $1.9 \pm 1.0$ \\
\hline Cesium-137 (pCi/L) (RESL) & $10 \pm 5$ & $4 \pm 6$ & $4 \pm 5$ & $7 \pm 7$ & $8 \pm 5$ \\
\hline Gross alpha (pCi/L) (RESL) & $2 \pm 2$ & $3 \pm 2$ & $2 \pm 2$ & $2 \pm 2$ & $2 \pm 2$ \\
\hline Gross beta (pCi/L) (RESL) & $3.3 \pm 0.8$ & $2.8 \pm 0.8$ & $1.8 \pm 0.7$ & $2.7 \pm 0.8$ & $1.7 \pm 0.8$ \\
\hline Americium-241 (pCi/L) (RESL) & $-0.013 \pm 0.014$ & $-0.005 \pm 0.014$ & $0.01 \pm 0.019$ & $-0.01 \pm 0.01$ & $0.01 \pm 0.02$ \\
\hline Plutonium-238 (pCi/L) (RESL) & $-0.009 \pm 0.006$ & $-0.007 \pm 0.012$ & $0.005 \pm 0.011$ & $-0.005 \pm 0.008$ & $0.006 \pm 0.01$ \\
\hline Oxygen-18 (per mil) (RSIL) & -17.54 & -17.63 & -17.54 & -17.60 & -17.55 \\
\hline \multicolumn{6}{|c|}{ Volatile organic compounds } \\
\hline Acrylonitrile & $<2.5$ & $<2.5$ & $<2.5$ & $<2.5$ & $<2.5$ \\
\hline Benzene & $<0.1$ & $<0.1$ & $<0.1$ & $<0.1$ & $<0.1$ \\
\hline Bromobenzene & $<0.2$ & $<0.2$ & $<0.2$ & $<0.2$ & $<0.2$ \\
\hline Bromochloromethane & $<0.2$ & $<0.2$ & $<0.2$ & $<0.2$ & $<0.2$ \\
\hline Bromomethane & $<0.3$ & $<0.3$ & $<0.3$ & $<0.3$ & $<0.3$ \\
\hline CFC-11 & $<0.2$ & $<0.2$ & $<0.2$ & $<0.2$ & $<0.2$ \\
\hline CFC-12 & $<0.2$ & $<0.2$ & $<0.2$ & $<0.2$ & $<0.2$ \\
\hline
\end{tabular}


Table 5. Concentrations of selected chemical and radiochemical constituents in water from well USGS 148A and select zones from multilevel well USGS 149, Materials and Fuels Complex, Idaho National Laboratory, Idaho, November 4-7, 2019._Continued

[See figure 1 for well location and figure 5 for multilevel well USGS 149 zones (Z1, Z3, Z5, and Z8) with data access through the National Water Information System (U.S. Geological Survey, 2021). Dates are in mm-dd-yyyy format, indicating month, day, year. Analytical results are in micrograms per liter unless noted otherwise. Bicarbonate data were calculated from alkalinity field measurements—alkalinity divided by 0.8202 (Hem, 1989, p. 57). Samples were analyzed at the USGS National Water Quality Laboratory in Lakewood, Colorado, unless otherwise indicated. Uncertainty of radiochemical constituents is 1 times the estimated sample standard deviation ( $1 \mathrm{~s}$ ). Uncertainty of deuterium and oxygen-18 is \pm 1.5 per mil. Concentrations that met or exceeded the reporting level of 3 times the $1 s$ value are shown in boldface type. Abbreviations and symbols: $\mathrm{CaCO}_{3}$, calcium carbonate; $\mathrm{CFC}$, chlorofluorocarbon; Menlo, USGS Menlo Park Tritium Laboratory, California; MTBE, methyl tert-butyl ether; N, nitrogen; P, phosphorus; RESL, Radiological and Environmental Sciences Laboratory; RSIL, USGS Reston Stable Isotope Laboratory, Virginia; USGS, U.S. Geological Survey; deg ${ }^{\circ} \mathrm{C}$, degrees Celsius; $\mu \mathrm{S} / \mathrm{cm}$, microsiemens per centimeter; $\mathrm{mg} / \mathrm{L}$, milligrams per liter; NTU, nephelometric turbidity units; pCi/L, picocuries per liter; NA, not applicable; <, less than; \pm , plus or minus]

\begin{tabular}{|c|c|c|c|c|c|}
\hline Constituent or measurement & $\begin{array}{l}\text { USGS 148A } \\
11-07-2019\end{array}$ & $\begin{array}{c}\text { USGS } 149 \text { Z1 } \\
11-05-2019\end{array}$ & $\begin{array}{c}\text { USGS } 149 \text { Z3 } \\
11-05-2019\end{array}$ & $\begin{array}{c}\text { USGS } 149 \text { Z5 } \\
11-05-2019\end{array}$ & $\begin{array}{c}\text { USGS } 149 \text { Z8 } \\
11-04-2019\end{array}$ \\
\hline CFC-113 & $<0.1$ & $<0.1$ & $<0.1$ & $<0.1$ & $<0.1$ \\
\hline Chlorobenzene & $<0.1$ & $<0.1$ & $<0.1$ & $<0.1$ & $<0.1$ \\
\hline Chloroethane & $<0.2$ & $<0.2$ & $<0.2$ & $<0.2$ & $<0.2$ \\
\hline cis-1,3-Dichloropropene & $<0.2$ & $<0.2$ & $<0.2$ & $<0.2$ & $<0.2$ \\
\hline Dibromochloropropane & $<0.5$ & $<0.5$ & $<0.5$ & $<0.5$ & $<0.5$ \\
\hline Dibromochloromethane & $<0.2$ & $<0.2$ & $<0.2$ & $<0.2$ & $<0.2$ \\
\hline Dibromomethane & $<0.2$ & $<0.2$ & $<0.2$ & $<0.2$ & $<0.2$ \\
\hline Isopropylbenzene & $<0.2$ & $<0.2$ & $<0.2$ & $<0.2$ & $<0.2$ \\
\hline MTBE & $<0.2$ & $<0.2$ & $<0.2$ & $<0.2$ & $<0.2$ \\
\hline Naphthalene & $<0.5$ & $<0.5$ & $<0.5$ & $<0.5$ & $<0.5$ \\
\hline n-Butylbenzene & $<0.2$ & $<0.2$ & $<0.2$ & $<0.2$ & $<0.2$ \\
\hline n-Propylbenzene & $<0.2$ & $<0.2$ & $<0.2$ & $<0.2$ & $<0.2$ \\
\hline sec-Butylbenzene & $<0.2$ & $<0.2$ & $<0.2$ & $<0.2$ & $<0.2$ \\
\hline Styrene & $<0.1$ & $<0.1$ & $<0.1$ & $<0.1$ & $<0.1$ \\
\hline tert-Butylbenzene & $<0.2$ & $<0.2$ & $<0.2$ & $<0.2$ & $<0.2$ \\
\hline Tetrachloroethene & $<0.1$ & $<0.1$ & $<0.1$ & $<0.1$ & $<0.1$ \\
\hline Trichloromethane & $<0.1$ & $<0.1$ & $<0.1$ & $<0.1$ & $<0.1$ \\
\hline Vinyl chloride & $<0.2$ & $<0.2$ & $<0.2$ & $<0.2$ & $<0.2$ \\
\hline Xylene & $<0.3$ & $<0.3$ & $<0.3$ & $<0.3$ & $<0.3$ \\
\hline 1,1,1-Trichloroethane & $<0.1$ & $<0.1$ & $<0.1$ & $<0.1$ & $<0.1$ \\
\hline 1,1,1,2-Tetrachloroethane & $<0.2$ & $<0.2$ & $<0.2$ & $<0.2$ & $<0.2$ \\
\hline 1,1,2,2-Tetrachloroethane & $<0.2$ & $<0.2$ & $<0.2$ & $<0.2$ & $<0.2$ \\
\hline 1,1,2-Trichloroethane & $<0.2$ & $<0.2$ & $<0.2$ & $<0.2$ & $<0.2$ \\
\hline 1,1-Dichloroethane & $<0.1$ & $<0.1$ & $<0.1$ & $<0.1$ & $<0.1$ \\
\hline
\end{tabular}


Table 5. Concentrations of selected chemical and radiochemical constituents in water from well USGS 148A and select zones from multilevel well USGS 149, Materials and Fuels Complex, Idaho National Laboratory, Idaho, November 4-7, 2019.—Continued

[See figure 1 for well location and figure 5 for multilevel well USGS 149 zones (Z1, Z3, Z5, and Z8) with data access through the National Water Information System (U.S. Geological Survey, 2021). Dates are in mm-dd-yyyy format, indicating month, day, year. Analytical results are in micrograms per liter unless noted otherwise. Bicarbonate data were calculated from alkalinity field measurements—alkalinity divided by 0.8202 (Hem, 1989, p. 57). Samples were analyzed at the USGS National Water Quality Laboratory in Lakewood, Colorado, unless otherwise indicated. Uncertainty of radiochemical constituents is 1 times the estimated sample standard deviation $(1 \mathrm{~s})$. Uncertainty of deuterium and oxygen-18 is \pm 1.5 per mil. Concentrations that met or exceeded the reporting level of 3 times the $1 s$ value are shown in boldface type. Abbreviations and symbols: $\mathrm{CaCO}_{3}$, calcium carbonate; $\mathrm{CFC}$, chlorofluorocarbon; Menlo, USGS Menlo Park Tritium Laboratory, California; MTBE, methyl tert-butyl ether; N, nitrogen; P, phosphorus; RESL, Radiological and Environmental Sciences Laboratory; RSIL, USGS Reston Stable Isotope Laboratory, Virginia; USGS, U.S. Geological Survey; deg ${ }^{\circ} \mathrm{C}$, degrees Celsius; $\mu \mathrm{S} / \mathrm{cm}$, microsiemens per centimeter; mg/L, milligrams per liter; NTU, nephelometric turbidity units; pCi/L, picocuries per liter; NA, not applicable; <, less than; \pm , plus or minus]

\begin{tabular}{|c|c|c|c|c|c|}
\hline Constituent or measurement & $\begin{array}{l}\text { USGS 148A } \\
11-07-2019 \\
\end{array}$ & $\begin{array}{c}\text { USGS } 149 \text { Z1 } \\
11-05-2019\end{array}$ & $\begin{array}{c}\text { USGS } 149 \text { Z3 } \\
11-05-2019\end{array}$ & $\begin{array}{c}\text { USGS } 149 \text { Z5 } \\
11-05-2019 \\
\end{array}$ & $\begin{array}{c}\text { USGS } 149 \text { Z8 } \\
11-04-2019\end{array}$ \\
\hline 1,1-Dichloroethene & $<0.1$ & $<0.1$ & $<0.1$ & $<0.1$ & $<0.1$ \\
\hline 1,2,3-Trichlorobenzene & $<0.2$ & $<0.2$ & $<0.2$ & $<0.2$ & $<0.2$ \\
\hline 1,2,3-Trichloropropane & $<0.2$ & $<0.2$ & $<0.2$ & $<0.2$ & $<0.2$ \\
\hline 1,2-Dibromoethane & $<0.2$ & $<0.2$ & $<0.2$ & $<0.2$ & $<0.2$ \\
\hline 1,2-Dichlorobenzene & $<0.1$ & $<0.1$ & $<0.1$ & $<0.1$ & $<0.1$ \\
\hline 1,2-Dichloroethane & $<0.2$ & $<0.2$ & $<0.2$ & $<0.2$ & $<0.2$ \\
\hline 1,2-Dichloropropane & $<0.1$ & $<0.1$ & $<0.1$ & $<0.1$ & $<0.1$ \\
\hline 1,4-Dichlorobenzene & $<0.1$ & $<0.1$ & $<0.1$ & $<0.1$ & $<0.1$ \\
\hline 2-Chlorotoluene & $<0.2$ & $<0.2$ & $<0.2$ & $<0.2$ & $<0.2$ \\
\hline 2,2-Dichloropropane & $<0.2$ & $<0.2$ & $<0.2$ & $<0.2$ & $<0.2$ \\
\hline 4-Chlorotoluene & $<0.2$ & $<0.2$ & $<0.2$ & $<0.2$ & $<0.2$ \\
\hline 4-Isopropyltoluene & $<0.2$ & $<0.2$ & $<0.2$ & $<0.2$ & $<0.2$ \\
\hline
\end{tabular}

\section{Analytical Methods}

Analytical methods used by the USGS for selected organic, inorganic, and radionuclide constituents are described by Goerlitz and Brown (1972), Thatcher and others (1977), Wershaw and others (1987), Fishman and Friedman (1989), Faires (1993), Fishman (1993), Rose and Schroeder (1995), and McCurdy and others (2008). Analytical methods used for selected isotopic constituents were summarized by Busenberg and others (2000). A discussion of procedures and methods used by the RESL for the analysis of radionuclides in water is provided by Bodnar and Percival (1982), Sill and Sill (1994), and the U.S. Department of Energy (1995).

\section{Guidelines for Interpretation of Analytical Results}

Concentrations of radionuclides are reported with an estimated sample standard deviation, $\boldsymbol{s}$, which is obtained by propagating sources of analytical uncertainty in measurements. McCurdy and others (2008) provided details on interpreting radiological data used by the USGS. The guidelines for interpreting analytical results are based on an extension of a method proposed by Currie (1984) that is given in Bartholomay and others (2020). In this report, radionuclide concentrations less than $3 \boldsymbol{s}$ are considered to be less than the "reporting level." The reporting level should not be confused with the analytical method detection limit, which is based on laboratory procedures.

Concentrations of inorganic and organic constituents are reported with reference to detection limits or reporting limits, respectively. Detection limits for inorganics were determined using the detection and quantification calculation (DQCALC) 
procedure as described in U.S. Geological Survey (2015) and the reporting limits for organic constituents were determined following the procedures described in Childress and others (1999).

As a matter of convention, concentrations of stable isotopes are reported as relative isotopic ratios (Toran, 1982). Busenberg and others (2000) described stable isotope data in more detail.

\section{Inorganic Chemistry Data}

Water-quality samples collected from well USGS 148A and the four zones in USGS 149 were analyzed by the NWQL for dissolved concentrations of cations, anions, and trace elements (table 5). Cations analyzed in this study included calcium, magnesium, potassium, silica, and sodium. Anions analyzed in this study included bromide, chloride, fluoride, and sulfate. Trace elements analyzed in this study included aluminum, antimony, arsenic, barium, beryllium, boron, cadmium, chromium, cobalt, copper, iron, lead, lithium, manganese, mercury, molybdenum, nickel, selenium, silver, strontium, thallium, tungsten, uranium, vanadium, and zinc. Additionally, samples collected and sent to the NWQL were analyzed for dissolved concentrations of ammonia as nitrogen $(\mathrm{N})$, nitrite as $\mathrm{N}$, nitrate plus nitrite as $\mathrm{N}$, and orthophosphate as phosphorus (table 5).

Water-quality sample data collected from well USGS $148 \mathrm{~A}$ indicate that calcium concentrations were 38.1 milligrams per liter $(\mathrm{mg} / \mathrm{L})$, potassium concentrations were 3.26 $\mathrm{mg} / \mathrm{L}$, silica concentrations were $34.2 \mathrm{mg} / \mathrm{L}$, chloride concentrations were $15.9 \mathrm{mg} / \mathrm{L}$, fluoride concentrations were 0.703 $\mathrm{mg} / \mathrm{L}$, and sulfate concentrations were $17.4 \mathrm{mg} / \mathrm{L}$ (table 5). The nitrate plus nitrite as $\mathrm{N}$ concentration $(2.42 \mathrm{mg} / \mathrm{L})$ in well USGS 148A was much larger than that of backgroundwater typical of the ESRP aquifer at the INL $(0.995 \mathrm{mg} / \mathrm{L}$; Bartholomay and Hall, 2016); however, larger concentrations also were detected in all four zones sampled in well USGS 149 (table 5). The large nitrate plus nitrite concentrations indicate that the groundwater along the eastern side of the MFC (fig. 1) is mostly eastern regional water that has some influence from upgradient anthropogenic processes. Cation and anion chemical constituent concentrations in well USGS 148A and all four zones in well USGS 149 show a calcium bicarbonate water chemistry (fig. 15). Rattray (2019) indicated that the water in this part of the aquifer is mostly eastern regional water with some minor influence from precipitation and irrigation return flow.

\section{Organic Chemistry Data}

Water-quality samples collected from wells USGS 148A and 149 were analyzed at the NWQL for volatile organic compounds (VOCs). All the VOCs had concentrations less than their laboratory MRLs (table 5), indicating that there is no organic contamination issue in the eastern part of the MFC and no remnant organics from the drilling process.

\section{Stable Isotope Data}

Water samples collected from wells USGS 148A and 149 were analyzed at the RSIL for relative concentrations of the stable isotopes of deuterium $\left({ }^{2} \mathrm{H}\right)$ and oxygen-18 $\left({ }^{18} \mathrm{O}\right)$. Because the absolute measurement of isotopic ratios is analytically difficult, relative isotopic ratios were measured instead (Toran, 1982) and are expressed in delta notation as part per mil (part per thousand difference). For example, the ${ }^{18} \mathrm{O} /{ }^{16} \mathrm{O}$ of a sample is compared with the ${ }^{18} \mathrm{O} /{ }^{16} \mathrm{O}$ of a standard:

$$
\delta{ }^{18} \mathrm{O}=\left(R_{\text {sample }} / R_{\text {standard }}-1\right) \times 1,000,
$$

where

$R_{\text {sample }}$ is the ${ }^{18} \mathrm{O} /{ }^{16} \mathrm{O}$ ratio in the sample,

$R_{\text {standard }}$ is the ${ }^{18} \mathrm{O} /{ }^{16} \mathrm{O}$ ratio in the standard, and

Delta $(\delta)^{18} \mathrm{O}$ is the relative concentration, in units of parts per thousand.

Delta $(\delta){ }^{18} \mathrm{O}$ is referred to as delta notation; it is the value reported by isotopic laboratories for stable isotope analysis. ${ }^{2} \mathrm{H} /{ }^{1} \mathrm{H}$ is defined in a similar manner with the respective ratios replacing ${ }^{18} \mathrm{O} /{ }^{16} \mathrm{O}$ in $R_{\text {sample }}$ and $R_{\text {standard }}$. The standard used for determining $\delta^{18} \mathrm{O}$ and $\delta^{2} \mathrm{H}$ in water is standard mean ocean water as defined by Craig (1961).

Stable isotopes were compared between wells USGS 148A and 149 to determine possible recharge sources and the relation of groundwater between the two wells. Stable isotope concentration data for deuterium and oxygen-18 samples collected from well USGS 148A were -134 and -17.54 per mil, respectively. Concentrations in all four zones of well USGS 149 were similar for oxygen-18 and slightly greater than in well USGS 148A, except in well USGS 149 (zone 3), which shows an equivalent concentration (table 5). Deuterium concentrations in all four zones of well USGS 149 were slightly greater than in well USGS 148A (table 5). Concentrations of deuterium and oxygen-18 isotopes were most similar to stable isotopes in Mud Lake surface water (Ott and others, 1994, table 4). Measured Mud Lake water shows enriched stable isotopes related to recirculation of irrigation water (Rattray, 2018).

\section{Radiochemical Data}

Water-quality samples collected from wells USGS 148A and 149 were analyzed at the RESL for strontium-90; gross alpha, beta, and gamma radioactivity; plutonium-238, and plutonium-239, -240 (undivided); and americium-241. Additionally, water-quality samples were analyzed for tritium and uranium isotopes at the USGS Menlo Park Research Laboratory and USGS NWQL contract laboratory, 


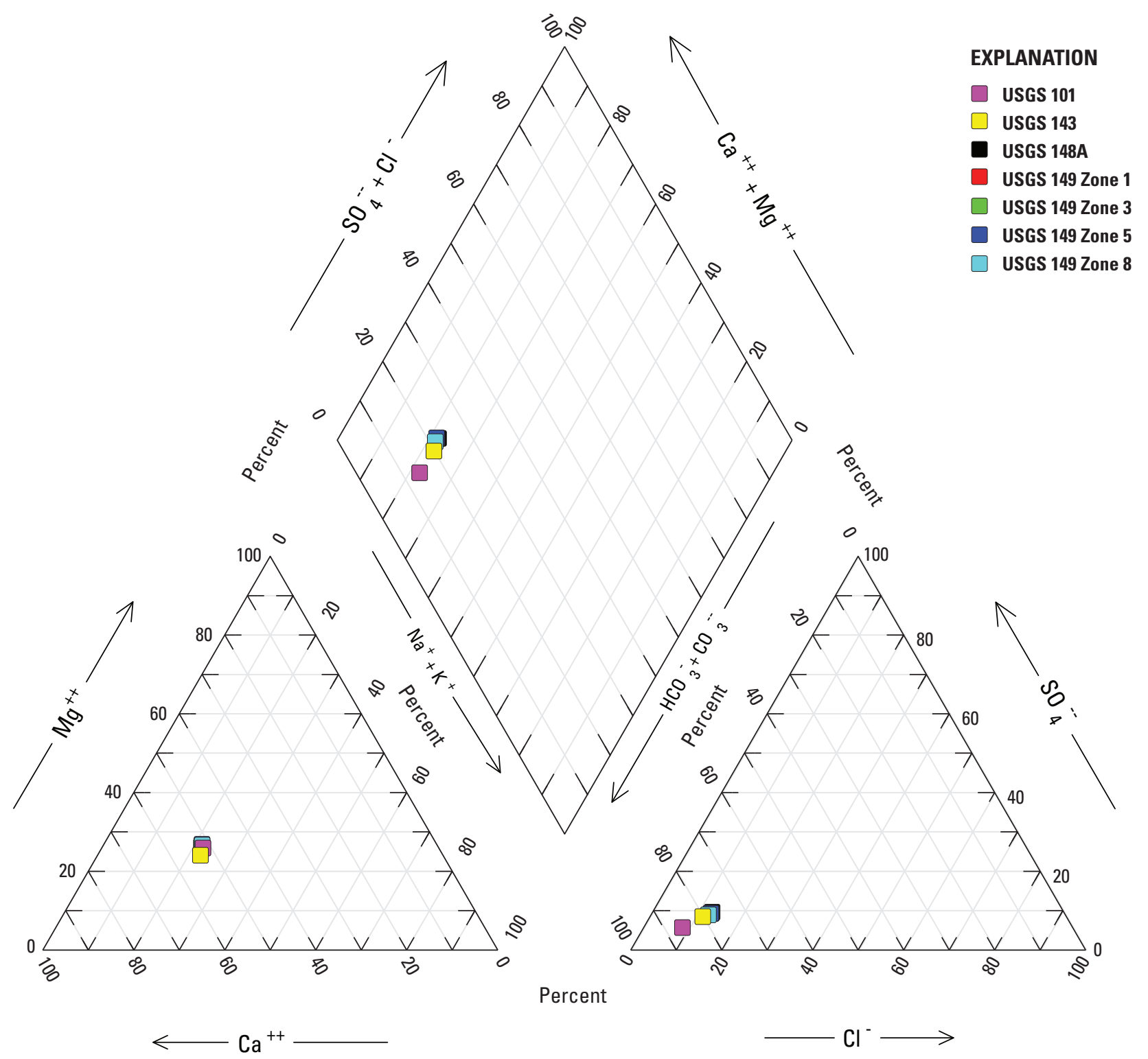

Figure 15. Cation and anion water chemistry for well USGS 148A and within four discrete zones in multilevel well USGS 149, Materials and Fuels Complex, Idaho National Laboratory, Idaho.

respectively (table 5). The concentrations of all radionuclides analyzed except for the following were less than the reporting level: tritium, gross beta, and uranium-234 and -238 (table 5). Concentrations of uranium-234, 238, and tritium were at background levels for the eastern regional Snake River Plain aquifer water at the INL (Bartholomay and Hall, 2016, table 1).

\section{Summary}

In 2019, the U.S. Geological Survey (USGS), in cooperation with the U.S. Department of Energy, drilled and constructed boreholes USGS 148A and 149 for stratigraphic framework analyses and long-term groundwater monitoring of the eastern Snake River Plain aquifer at the Idaho National Laboratory in southeastern Idaho. Boreholes USGS 148A and 149 initially were cored to collect continuous geologic data and then repurposed as monitoring wells following construction and data collection. On completion of data collection, well USGS 148A was repurposed as a monitoring well. Well USGS 149 was repurposed as a multilevel monitoring well configured with one continuous system that allows for water sampling and collection of pressure head and fluid temperature from discrete zones and from multiple depths within a single borehole.

Core material was collected at both borehole locations, starting from the first basalt contact to total depth. Drilling mud was used to help improve recovery and grout was used 
to stabilize difficult sections of the borehole to advance core drilling. Borehole USGS 149 was continuously cored, starting at $6.5 \mathrm{feet}(\mathrm{ft}$ ) to a final construction depth of $973.7 \mathrm{ft}$ below land surface (BLS). Boreholes USGS 148 and 148A originate from the same surface location; however, the section of borehole USGS 148 from 136.3 to $264.1 \mathrm{ft}$ BLS was abandoned during the construction. Borehole USGS 148A was continuously cored from $136.3 \mathrm{ft}$ to $759.2 \mathrm{ft}$ BLS.

Excluding surface sediment, more than 96 percent of basalt and sediment core was recovered at borehole USGS 148A and more than 98 percent was recovered at borehole USGS 149. The core material was composed mostly of basalt with thin sediment layers located within the unsaturated zone. Basalt texture for both borehole locations was described as aphanitic, phaneritic, and porphyritic. Basalt flows varied from highly fractured to dense with high to low vesiculation. Excluding surface sediment, five sediment layers are described for borehole USGS 148A, ranging from 1.0 to $6.8 \mathrm{ft}$ in thickness. Six sediment layers were described for borehole USGS 149, ranging from 0.2 to $7.3 \mathrm{ft}$ in thickness. Sediment-layer location and thickness, described for boreholes USGS 149 and $148 \mathrm{~A}$, were very similar. With the exception of an ash layer described near $35.1 \mathrm{ft}$ BLS and a sandstone layer described near $579.6 \mathrm{ft} \mathrm{BLS} \mathrm{in} \mathrm{borehole} \mathrm{USGS} \mathrm{149,} \mathrm{the} \mathrm{general} \mathrm{com-}$ position of sediment at both borehole locations is composed mostly of fine-grained sand, silt, and clay deposits that were extremely firm and structureless.

Geophysical and borehole video logs were collected by the USGS after core drilling at boreholes USGS 148A and 149. Geophysical logs were examined in conjunction with the core material to suggest the occurrence of fractured and (or) vesiculated basalt, dense basalt, and sediment layering in the saturated and unsaturated zones. Additionally, gyroscopic deviation measurements were used to evaluate each borehole trajectory by measuring the horizontal and vertical displacement within boreholes USGS 148A and 149.

A single-well aquifer test was done during November 6-7, 2019, following construction at well USGS 148A. Estimates for transmissivity and hydraulic conductivity were $6.34 \times 10^{3}$ feet squared per day and 3.17 feet per day, respectively. The aquifer test was run overnight (21.3 hours) and measured drawdown was relatively small $(0.09 \mathrm{ft})$ at sustained pumping rates ranging from 15.7 to 16.1 gallons per minute. The transmissivity estimates for well USGS 148A were comparable to those determined from previous aquifer tests for wells near the Materials and Fuels Complex.

Water samples were analyzed for cations, anions, metals, nutrients, volatile organic compounds, stable isotopes, and radionuclides. Water samples for most of the inorganic constituents showed similar chemistry in USGS 148A and all four zones in USGS 149. Water samples for stable isotopes of oxygen and hydrogen indicated possible influence of irrigation on the water quality. Nitrate plus nitrite concentrations indicated influence from anthropogenic sources. The volatile organic compound and radiochemical data indicated that these wells had no detectable influence from wastewater disposal practices at the Materials and Fuels Complex or from drilling.

\section{References Cited}

Ackerman, D.J., 1991, Transmissivity of the Snake River Plain aquifer at the Idaho National Engineering Laboratory, Idaho: U.S. Geological Survey Water-Resources Investigations Report 91-4058 (DOE/ID-22097), 35 p. [Also available at https://doi.org/10.3133/wri914058.]

Ackerman, D.J., Rattray, G.W., Rousseau, J.P., Davis, L.C., and Orr, B.R., 2006, A conceptual model of ground-water flow in the eastern Snake River Plain aquifer at the Idaho National Laboratory and vicinity with implications for contaminant transport: U.S. Geological Survey Scientific Investigations Report 2006-5122, 62 p. [Also available at https://doi.org/10.3133/sir20065122.]

Ackerman, D.J., Rousseau, J.P., Rattray, G.W., and Fisher, J.C., 2010, Steady-state and transient models of groundwater flow and advective transport, Eastern Snake River Plain aquifer, Idaho National Laboratory and vicinity, Idaho: U.S. Geological Survey Scientific Investigations Report 2010-5123, 220 p. [Also available at https://doi.org/ 10.3133/sir20105123.]

Anderson, S.R., Kuntz, M.A., and Davis, L.C., 1999, Geologic controls of hydraulic conductivity in the Snake River Plain aquifer at and near the Idaho National Engineering and Environmental Laboratory, Idaho: U.S. Geological Survey Water-Resources Investigations Report 99-4033 (DOE/ ID-22155), 38 p. [Also available at https://doi.org/10.3133/ wri994033.]

Anderson, S.R., and Liszewski, M.J., 1997, Stratigraphy of the unsaturated zone and the Snake River Plain aquifer at and near the Idaho National Engineering Laboratory, Idaho: U.S. Geological Survey Water-Resources Investigations Report 97-4183 (DOE/ID-22142), 65 p. [Also available at https://doi.org/10.3133/wri974183.]

Bartholomay, R.C., and Hall, L.F., 2016, Evaluation of background concentrations of selected chemical and radiochemical constituents in water from the eastern Snake River Plain aquifer at and near the Idaho National Laboratory, Idaho: U.S. Geological Survey Scientific Investigations Report 2016-5056 (DOE/ID-22237), 19 p. [Also available at https://doi.org/10.3133/sir20165056.] 
Bartholomay, R.C., Maimer, N.V., Rattray, G.W., and Fisher, J.C., 2020, An update of hydrologic conditions and distribution of selected constituents in water, eastern Snake River Plain aquifer and perched groundwater zones, Idaho National Laboratory, Idaho, emphasis 2016-18: U.S. Geological Survey Scientific Investigations Report 2019-5149 (DOE/ID-22251), 82 p. [Also available at https://doi.org/10.3133/sir20195149.]

Bartholomay, R.C., Maimer, N.V., and Wehnke, A.J., 2014, Field methods and quality-assurance plan for waterquality activities and water-level measurements, U.S. Geological Survey, Idaho National Laboratory, Idaho: U.S. Geological Survey Open-File Report 2014-1146 (DOE/ ID-22230), 66 p. [Also available at https://doi.org/10.3133/ ofr20141146.]

Bartholomay, R.C., Tucker, B.J., Ackerman, D.J., and Liszewski, M.J., 1997, Hydrologic conditions and distribution of selected radiochemical and chemical constituents in water, Snake River Plain aquifer, Idaho National Engineering Laboratory, Idaho, 1992 through 1995: U.S. Geological Survey Water-Resources Investigations Report 97-4086 (DOE/ID-22137), 57 p. [Also available at https://doi.org/10.3133/wri974086.]

Blackwell, D.D., Kelley, S., and Steele, J.L., 1992, Heat flow modeling of the Snake River Plain, Idaho: Idaho National Engineering Laboratory, Department of Energy contractor report no. EGG-NPR-10790, 109 p.

Bodnar, L.Z., and Percival, D.R., eds., 1982, RESL Analytical Chemistry Branch procedures manual: U.S. Department of Energy Report IDO-12096, 364 p.

Busenberg, E., Plummer, L.N., and Bartholomay, R.C., 2001, Estimated age and source of the young fraction of ground water at the Idaho National Engineering and Environmental Laboratory: U.S. Geological Survey Water-Resources Investigations Report 2001-4265 (DOE/ID-22177), 144 p. [Also available at https://doi.org/10.3133/wri014265.]

Busenberg, E., Plummer, L.N., Doughten, M.W., Widman, P.K., and Bartholomay, R.C., 2000, Chemical and isotopic composition and gas concentrations of ground water and surface water from selected sites at and near the Idaho National Engineering and Environmental Laboratory, Idaho, 1994-97: U.S. Geological Survey Open-File Report 2000-81 (DOE/ ID-22164), 51 p. [Also available at https://doi.org/10.3133/ofr0081.]
Cecil, L.D., Welhan, J.A., Green, J.R., Frape, S.K., and Sudicky, E.R., 2000, Use of chlorine-36 to determine regional-scale aquifer dispersivity, eastern Snake River Plain aquifer, Idaho/USA in Nuclear instruments and methods in physics research section B-Beam interactions with materials and atoms: 8th International Conference on Accelerator Mass Spectrometry, Vienna, Austria, 1999, v. 172, p. 679-687.

Childress, C.J.O., Foreman, W.T., Connor, B.F., and Maloney, T.J., 1999, New reporting procedures based on long-term method detection levels and some considerations for interpretations of water-quality data provided by the U.S. Geological Survey National Water Quality Laboratory: U.S. Geological Survey Open-File Report 99-193, 19 p. [Also available at https://doi.org/10.3133/ofr99193.]

Christensen Products, 1997, C wireline system: Christensen Products web page, accessed May 2008, at http://chr istensenproducts.com.

Cooper, H.H., Jr., and Jacob, C.E., 1946, A generalized graphical method for evaluating formation constants and summarizing well field history: Eos, Transactions-American Geophysical Union, v. 27, no. 4, p. 526-534.

Craig, H., 1961, Isotopic variation in meteoric water: Science, v. 133 , no. 3465 , p. $1702-1703$.

Currie, L.A., 1984, Lower limit of detection-Definition and elaboration of a proposed position for radiological effluent and environmental measurements: Prepared for the U.S. Nuclear Regulatory Commission by the National Bureau of Standards, NUREG/CR-4007, 139 p.

Duke, C.L., Roback, R.C., Reimus, P.W., Bowman, R.S., McLing, T.L., Baker, K.E., and Hull, L.C., 2007, Elucidation of flow and transport processes in a variably saturated system of interlayered sediment and fractured rock using tracer tests: Vadose Zone Journal, v. 6, no. 4, p. $855-867$.

Faires, L.M., 1993, Methods of analysis by the U.S. Geological Survey National Water Quality LaboratoryDetermination of metals in water by inductively coupled plasma-mass spectrometry: U.S. Geological Survey OpenFile Report 92-634, 28 p. [Also available at https://doi.org/ 10.3133/ofr92634.]

Fisher, J.C., and Twining, B.V., 2011, Multilevel groundwater monitoring of hydraulic head and temperature in the eastern Snake River Plain aquifer, Idaho National Laboratory, Idaho, 2007-08: U.S. Geological Survey Scientific Investigations Report 2010-5253, $62 \mathrm{p}$. 
Fishman, M.J., ed., 1993, Methods of analysis by the U.S. Geological Survey National Water Quality LaboratoryDetermination of inorganic and organic constituents in water and fluvial sediments: U.S. Geological Survey OpenFile Report 93-125, 217 p. [Also available at https://doi.org/ 10.3133/ofr93125.]

Fishman, M.J., and Friedman, L.C., eds., 1989, Methods for determination of inorganic substances in water and fluvial sediments ( $3 \mathrm{~d}$ ed.): U.S. Geological Survey Techniques of Water-Resources Investigations, book 5, chap. A1, 545 p. [Also available at https://doi.org/10.3133/twri05A1.]

Freeze, R.A., and Cherry, J.A., 1979, Groundwater: Englewood Cliffs, New Jersey, Prentice Hall, Inc., 604 p.

Garabedian, S.P., 1986, Application of a parameter-estimation technique to modeling the regional aquifer underlying the eastern Snake River Plain, Idaho: U.S. Geological Survey Water-Supply Paper 2278, 60 p. [Also available at https://doi.org/10.3133/wsp2278.]

Goerlitz, D.F., and Brown, E., 1972, Methods for analysis of organic substances in water: U.S. Geological Survey Techniques of Water-Resources Investigations, book 5, chap. A3, 40 p. [Also available at https://doi.org/10.3133/ twri05A3_1972.]

Halford, K.J., Weight, W.D., and Schreiber, R.P., 2006, Interpretation of transmissivity estimates from singlewell pumping aquifer tests: Ground Water, v. 44, no. 3, p. $467-471$.

Hem, J.D., 1989, Study and interpretation of the chemical characteristics of natural water (3d ed.): U.S. Geological Survey Water Supply Paper 2254, 263 p.

Keys, W.S., 1990, Borehole geophysics applied to groundwater investigations: U.S. Geological Survey Techniques of Water-Resources Investigations, book 2, chap. E2, 150 p. [Also available at https://doi.org/10.3133/twri02E2.]

Mann, L.J., 1986, Hydraulic properties of rock units and chemical quality of water for INEL-1-A 10,365-foot deep test hole drilled at the Idaho National Engineering Laboratory, Idaho: U.S. Geological Survey Water-Resources Investigations Report 86-4020 (IDO-22070), 23 p. [Also available at https://doi.org/10.3133/wri864020.]

Mann, L.J., and Beasley, T.M., 1994, Iodine-129 in the Snake River Plain aquifer at and near the Idaho National Engineering Laboratory, Idaho, 1990-91: U.S. Geological Survey Water-Resources Investigations Report 94-4053 (DOE/ID-22115), 27 p. [Also available at https://doi.org/ 10.3133/wri944053.]
McCurdy, D.E., Garbarino, J.R., and Mullin, A.H., 2008, Interpreting and reporting radiological water-quality data: U.S. Geological Survey Techniques and Methods, book 5, chap. B6, 33 p. [Also available at https://doi.org/ 10.3133/tm5B6.]

Nimmo, J.R., Perkins, K.S., Rose, P.E., Rousseau, J.P., Orr, B.R., Twining, B.V., and Anderson, S.R., 2002, Kilometerscale rapid transport of naphthalene sulfonate tracer in the unsaturated zone at the Idaho National Engineering and Environmental Laboratory: Vadose Zone Journal, v. 1, no. 1, p. 89-101. [Also available at https://doi.org/10.2136/ vzj2002.8900.]

Ott, D.S., Cecil, L.D., and Knobel, L.L., 1994, Stable isotopes of hydrogen and oxygen in surface water and ground water at selected sites on or near the Idaho National Engineering Laboratory, Idaho: U.S. Geological Survey Open-File Report 94-55 (DOE/ID-22112), 14 p. [Also available at https://doi.org/10.3133/ofr9455.]

Pierce, K.L., and Morgan, L.A., 1992, The track of the Yellowstone hot spot, chap. 1 of Link, P.K., Kuntz, M.A., and Platt, L.B., eds., Regional geology of eastern Idaho and western Wyoming: Geological Society of America Memoir 179, p. 1-53.

Plummer, L.N., Rupert, M.G., Busenberg, E., and Schlosser, P., 2000, Age of irrigation water in ground water from the eastern Snake River Plain aquifer, south-central Idaho: Ground Water, v. 38, no. 2, p. 264-283.

Pritt, J.W., 1989, Quality assurance of sample containers and preservatives at the U.S. Geological Survey National Water Quality Laboratory, in Pederson, G.L., and Smith, M.M., comps., U.S. Geological Survey second national symposium on water quality-Abstracts of the technical sessions, Orlando, Florida, November 12-17, 1989: U.S. Geological Survey Open-File Report 89-409, 111 p. [Also available at https://doi.org/10.3133/ofr89409.]

Rattray, G.W., 2018, Geochemistry of groundwater in the eastern Snake River Plain aquifer, Idaho National Laboratory and vicinity, eastern Idaho: U.S. Geological Survey Professional Paper 1837-A, 198 p. [Also available at https://doi.org/10.3133/pp1837A.]

Rattray, G.W., 2019, Evaluation of chemical and hydrologic processes in the eastern Snake River Plain aquifer based on results from geochemical modeling, Idaho National Laboratory, eastern Idaho: U.S. Geological Survey Professional Paper 1837-B (DOE/ID-22248), 85 p., https://doi.org/10.3133/pp1837B. 
Robertson, J.B., Schoen, R., and Barraclough, J.T., 1974, The influence of liquid waste disposal on the geochemistry of water at the National Reactor Testing Station, Idaho, 1952-1970: U.S. Geological Survey Open-File Report 73-238 (IDO-22053), 231 p. [Also available at https://doi.org/10.3133/ofr73238.]

Rose, D.L., and Schroeder, M.P., 1995, Methods of analysis by the U.S. Geological Survey National Water Quality Laboratory-Determination of volatile organic compounds in water by purge and trap capillary gas chromatography/ mass spectrometry: U.S. Geological Survey Open-File Report 94-708-W, 26 p. [Also available at https://doi.org/ 10.3133/ofr94708W.]

Self, S., Keszthelyi, L., and Thordarson, T., 1998, The importance of pahoehoe: Annual Review of Earth and Planetary Sciences, v. 26, no. 1, p. 81-110.

Shervais, J.W., Vetter, S.K., and Hanan, B.B., 2006, Layered mafic sill complex beneath the eastern Snake River PlainEvidence from cyclic geochemical variations in basalt: Geology, v. 34, no. 5, p. 365-368.

Sill, D.S., and Sill, C.W., 1994, Simultaneous determination of the actinides in small environmental samples: Radioactivity and Radiochemistry, v. 5, no. 2, p. 8-19.

Thatcher, L.L., Janzer, V.J., and Edwards, K.W., 1977, Methods for determination of radioactive substances in water and sediments: U.S. Geological Survey Techniques of Water-Resources Investigations, book 5, chap. A5, 95 p. [Also available at https://doi.org/10.3133/twri05A5.]

Theis, C.V., 1935, The relation between the lowering of the piezometric surface and the rate and duration of discharge of a well using groundwater storage: Eos, TransactionsAmerican Geophysical Union, v. 16, no. 2, p. 519-524.

Toran, L., 1982, Isotopes in ground-water investigations: Ground Water, v. 20, no. 6, p. 740-745.

Twining, B.V., 2016, Borehole deviation and correction factor data for selected wells in the eastern Snake River Plain aquifer at and near the Idaho National Laboratory, Idaho: U.S. Geological Survey Scientific Investigations Report 2016-5163 (DOE/ID-22241), 23 p., plus appendixes, [Also available at https://doi.org/10.3133/sir20165163.]

Twining, B.V., Bartholomay, R.C., and Hodges, M.K.V., 2014, Completion summary for boreholes USGS 140 and USGS 141 near the Advanced Test Reactor Complex, Idaho National Laboratory, Idaho: U.S. Geological Survey Scientific Investigations Report 2014-5098 (DOE/ ID-22229), 40 p., plus appendixes, https://doi.org/10.3133/ sir20145098.
Twining, B.V., and Fisher, J.C., 2012, Multilevel groundwater monitoring of hydraulic head and temperature in the eastern Snake River Plain aquifer, Idaho National Laboratory, Idaho, 2009-2010: U.S. Geological Survey Scientific Investigations Report 2012-5259 (DOE/ID-22221), 44 p., plus appendixes, https://doi.org/10.3133/sir20125259.

Twining, B.V., and Fisher, J.C., 2015, Multilevel groundwater monitoring of hydraulic head and temperature in the eastern Snake River Plain aquifer, Idaho National Laboratory, Idaho, 2011-2013: U.S. Geological Survey Scientific Investigations Report 2015-5042 (DOE/ID-22235), 49 p., https://doi.org/10.3133/sir20155042.

Twining, B.V., and Maimer, N.V., 2019, Transmissivity and geophysical data for selected wells located at and near the Idaho National Laboratory, Idaho, 2017-18: U.S. Geological Survey Scientific Investigations Report 2019-5134, 30 p., plus appendixes, https://doi.org/10.3133/ sir20195134.

U.S. Department of Energy, 1995, Radiochemistry manual, rev. 10: Idaho Falls, Idaho, U.S. Department of Energy, Radiological and Environmental Sciences Laboratory. [variously paged].

U.S. Geological Survey, 1985, National water summary 1984-Hydrologic events, selected water-quality trends, and ground-water resources: U.S Geological Survey Water-Supply Paper 2275, 467 p. [Also available at https://doi.org/10.3133/wsp2275.]

U.S. Geological Survey, 2015, Changes to National Water Quality Laboratory (NWQL) procedures used to establish and verify laboratory detection and reporting limits: National Water Quality Laboratory Technical Memorandum 15.02, accessed January 26, 2020, at https://nwql.usgs.gov/ tech_memos/nwql.2015-02.pdf.

U.S. Geological Survey, 2019, USGS GeoLog Locator: U.S. Geological Survey web interface, accessed June 20, 2019, at https://doi.org/10.5066/F7X63KT0.

U.S. Geological Survey, 2021, National Water Information System: U.S. Geological Survey web interface, http://dx.doi.org/10.5066/F7P55KJN, accessed May 2021, at https://nwis.waterdata.usgs.gov/nwis.

U.S. Geological Survey, [variously dated], National field manual for the collection of water-quality data: U.S. Geological Survey Techniques of Water-Resources Investigations, book 9, chaps. A1-A9, [Also available at https://water.usgs.gov/owq/FieldManual/.] 
Wershaw, R.L., Fishman, M.J., Grabbe, R.R., and Lowe, L.E., eds., 1987, Methods for the determination of organic substances in water and fluvial sediments: U.S. Geological Survey Techniques of Water-Resources Investigations, book 5, chap. A3, 80 p. [Also available at https://doi.org/10.3133/ twri05A3.]

Whitehead, R.L., 1992, Geohydrologic framework of the Snake River Plain regional aquifer system, Idaho and eastern Oregon: U. S. Geological Survey Professional Paper 1408-B, 32 p. [Also available at https://doi.org/10.3133/ pp1408B.]
Williams, J.H., and Johnson, C.D., 2004, Acoustic and optical borehole-wall imaging for fractured-rock aquifer studies: Journal of Applied Geophysics, v. 55, nos. 1-2, p. 151-159. 


\section{Appendix 1. Completion Report for Multilevel Well USGS 149}

Appendix 1 is an Adobe Acrobat ${ }^{\circledR}$ PDF file available for download at https://doi.org/ 10.3133/sir20215131. The contributions by non-U.S. Geological Survey (USGS) authors in this appendix 1 are published as they were submitted. Research was supported by the USGS under USGS Order No. 140G0319P0203, dated June 25, 2019. The views and conclusions contained in appendix 1 are those of the non-USGS authors and should not be interpreted as necessarily representing the views, official policies, either expressed or implied, of the U.S. Government. Any use of trade, firm, or product names is for descriptive purposes only and does not imply endorsement by the U.S. Government.

\section{Appendix 2. Driller Log for USGS 148A (Previously USGS 148)}

Appendix 2 is an Adobe Acrobat ${ }^{\circledR}$ PDF file available for download at https://doi.org/10.3133/sir20215131.

\section{Appendix 3. Driller Log for USGS 149}

Appendix 3 is an Adobe Acrobat ${ }^{\circledR}$ PDF file available for download at https://doi.org/10.3133/sir20215131.

\section{Appendix 4. Core Log for USGS 148}

Appendix 4 is an Adobe Acrobat ${ }^{\circledR}$ PDF file available for download at https://doi.org/10.3133/ sir20215131.

\section{Appendix 5. Core Log for USGS 148A}

Appendix 5 is an Adobe Acrobat ${ }^{\circledR}$ PDF file available for download at https://doi.org/10.3133/sir20215131.

\section{Appendix 6. Core Log for USGS 149}

Appendix 6 is an Adobe Acrobat ${ }^{\circledR}$ PDF file available for download at https://doi.org/10.3133/sir20215131. 
Publishing support provided by the U.S. Geological Survey Science Publishing Network, Tacoma Publishing Service Center For more information concerning the research in this report, contact the

Director, Idaho Water Science Center

U.S. Geological Survey

230 Collins Road

Boise, Idaho 83702-4520

https://www.usgs.gov/centers/id-water 
